\title{
Debate en torno a las formas del audiovisual contemporáneo de superhéroes
}

\author{
Elisa McCausland y Diego Salgado
}

Elisa McCausland (Madrid, 1983) es periodista, crítica e investigadora especializada en cultura popular. Trabaja en su tesis investigando el arquetipo superheroico y su potencial feminista centrado en Wonder Woman. Sus ensayos pueden leerse en los libros Vengadores: Poder Absoluto (2013), Watchmen: Radiografias de una explosión (2013), Batman desde la periferia (2013), Los héroes están muertos (2014) y Yo soy más de series (2015). Ha participado en la compilación de cómic Enjambre (Norma, 2014). Escribe regularmente sobre cómic, cine y literatura en el periódico Diagonal, y debate sobre las mismas cuestiones en el programa radiofónico Perros Verdes. Dirige el programa radiofónico de cómic Isla Paraíso en El Estado Mental. Participa en los fanzines Rantifuso (desde 2005) y Malavida (desde 2012). Aborda cómic y feminismo en el fanzine sonoro Sangre Fucsia, el programa de radio online Rock \& Cómics, y las webs Pikara Magazine, Canino Magazine e Inquire Project. Ha colaborado en medios como Radio 3, El Diario, Agente Provocador, Rockdelux, Quimera, Vein y Madriz, entre otros. Es una de las promotoras del Colectivo de Autoras de Cómic (AC).

Diego Salgado (Madrid, 1967) es crítico de cine. Actualmente, escribe con regularidad en Cine para Leer, Détour, Diagonal, Dirigido Por y Guía del Ocio, y participa en el programa radiofónico Perros Verdes. Colaborador entre 2005 y 2015 de FanDigital, entre 2008 y 2011 de Cahiers du Cinéma España, entre 2008 y 2016 de Miradas de Cine, y entre 2011 y 2013 de El Rayo Verde. Participante en libros colectivos como Cien Miradas de Cine (2011), John Carpenter: Ultimátum a la Tierra (2013), A Tumba Abierta: El Cine Kamikaze (2014), El universo de '2001: Una odisea del espacio' (2014), Werner Herzog: Espejismos de sueños olvidados (2015) y Antología del Cine Fantástico y de Terror Español (2015-2016). Ponente sobre crítica y cine en los cursos de verano de la Universidad Complutense de Madrid y otras instituciones. Colaborador ocasional en medios como Imágenes de Actualidad, L'Atalante, El Destilador Cultural, Transit, Visual404, IGN España, Numerocero y Cine Divergente. Participante en ediciones críticas diversas en DVD. Miembro de la OFCS (Online Film Critics Society).

Fecha de recepción: 13 de mayo de 2016

Fecha de aceptación definitiva: 18 de mayo de 2016 
El cine y la televisión de hoy viven un boom de lo superheroico, y registros argumentales asociados, inédito en la historia de ambos medios. Un boom que, al estar los entretenimientos populares más interconectados que nunca, ha propiciado además, en palabras de Francisco Calderón - actual director editorial de ECC, que ostenta los derechos para publicar las cabeceras de DC Comics en España y Sudamérica-, «que el cómic pase por una buena época, haya encontrado su espacio y esté en alza». ${ }^{1}$ Pero, este auge de los superhéroes en la pantalla, que se ha venido fraguando a lo largo del último cuarto de siglo y que dio lugar entre 2008 y 2015 a que cinco muestras cinematográficas del género se situasen entre las veinticinco películas más taquilleras de todos los tiempos, ¿ha tenido el correlato expresivo deseado? ¿Cuál es el saldo creativo de esta preeminencia del superhéroe en la esfera sociocultural contemporánea?

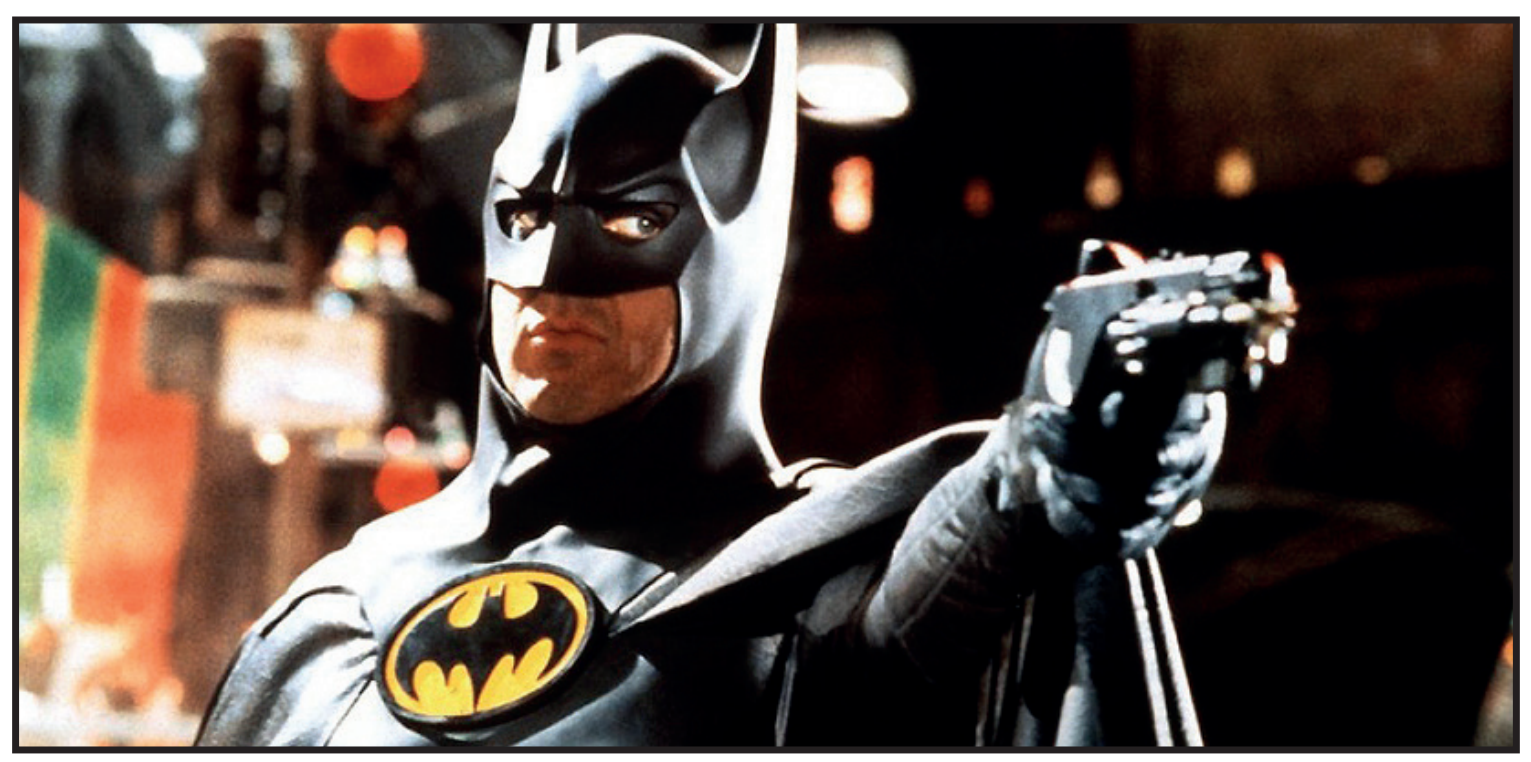

FIG. 1. Batman (íd. Tim Burton, 1989).

Diego Salgado: Creo que nos hallamos en un punto idóneo para valorar hasta qué punto el cine y la televisión en torno a los superhéroes han logrado emanciparse respecto a los cómics en los que casi siempre se inspiran; para preguntarnos si han logrado articular desde Batman (íd. Tim Burton, 1989) y, más en especial, desde Spider-Man (íd. Sam Raimi, 2002), unas formas significativas, independientes de las viñetas y, a la vez, capaces de establecer un diálogo con estas, así como con voluntad para aportar estilemas perdurables al audiovisual de masas. Tú y yo hemos comentado estos temas en numerosas ocasiones, pero

${ }^{1}$ EFE. «Las editoriales de cómics se arremangan para combatir la incertidumbre», en El Mundo (1 de mayo de 2016). Disponible online en http://www.elmundo.es/cultura/2016/05/01/5725e8d346163f790a8b45c2.html 
puede que valga la pena poner nuestras ideas en común en un año como 2016, que ha visto ya los estrenos - y aún estamos en mayo- de Deadpool (íd. Tim Miller, 2016), Batman $v$ Superman: El amanecer de la justicia (Batman v Superman: Dawn of Justice. Zack Snyder, 2016), Capitán América: Civil War (Captain America: Civil War. Joe \& Anthony Russo, 2016) y X-Men: Apocalipsis (X-Men: Apocalypse. Bryan Singer, 2016), y la emisión de series con tanta repercusión entre los aficionados como Jessica Jones (íd. Melissa Rosenberg para Netflix, 2015), Supergirl (íd. Ali Alder, Greg Berlanti y Andrew Kreisberg para CBS, 20152016), Agente Carter (Agent Carter. Christopher Markus y Stephen McFeely para ABC, 2015-2016) o Daredevil (íd. Drew Goddard para Netflix, 2015-2016). Aunque tenemos un largo debate por delante, me gustaría apuntar desde este momento inicial ciertas dudas ante lo que, en un primer vistazo, podría indicar que nos encontramos en un momento de autoridad y madurez plenas del género, ${ }^{2}$ pero que, observado con atención, no pasa de ser un estado de aplicación generalizada de fórmulas lejos de lo rompedor. Fórmulas que han dignificado e incluso glamourizado al superhéroe de cara a la imagen en movimiento - algo desde luego muy meritorio, impensable hasta hace unos años, baste con recordar las no tan lejanas Captain America (Albert Pyun, 1990) y The Fantastic Four (Oley Sassone, 1994)-, pero, a costa, quizás, de su adaptación a unos ecosistemas de producción y recepción muy conservadores, en los que se prima sobre todo la sumisión interesada al fan, lo iconográfico, la literalidad, la corrección ideológica y por extensión visual; una concepción del espectáculo saneada y agradable, no demasiado inventiva. Desde luego, ni desafiante, ni incómoda, ni artística en el sentido de subvertir nuestra mirada.

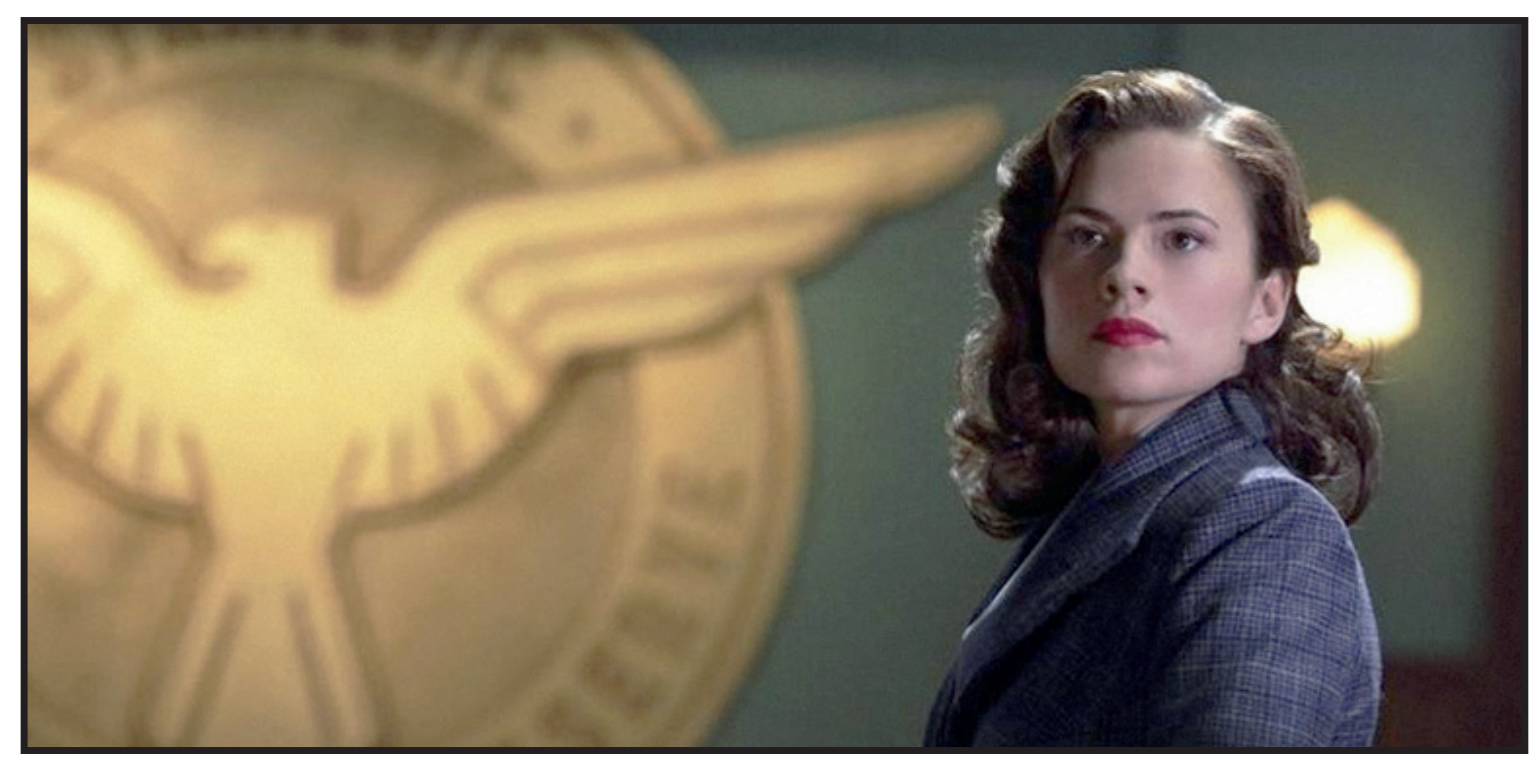

FIG. 2. Agente Carter (Agent Carter. Chris Markus y Stephen McFeely para ABC, 2015-2016).

2 Salgado, D. «El nuevo cine de superhéroes», en Cine para Leer (24 de abril de 2016). Disponible online en http://www.cineparaleer.com/punto-de-vista/item/1889-el-nuevo-cine-de-superheroes 


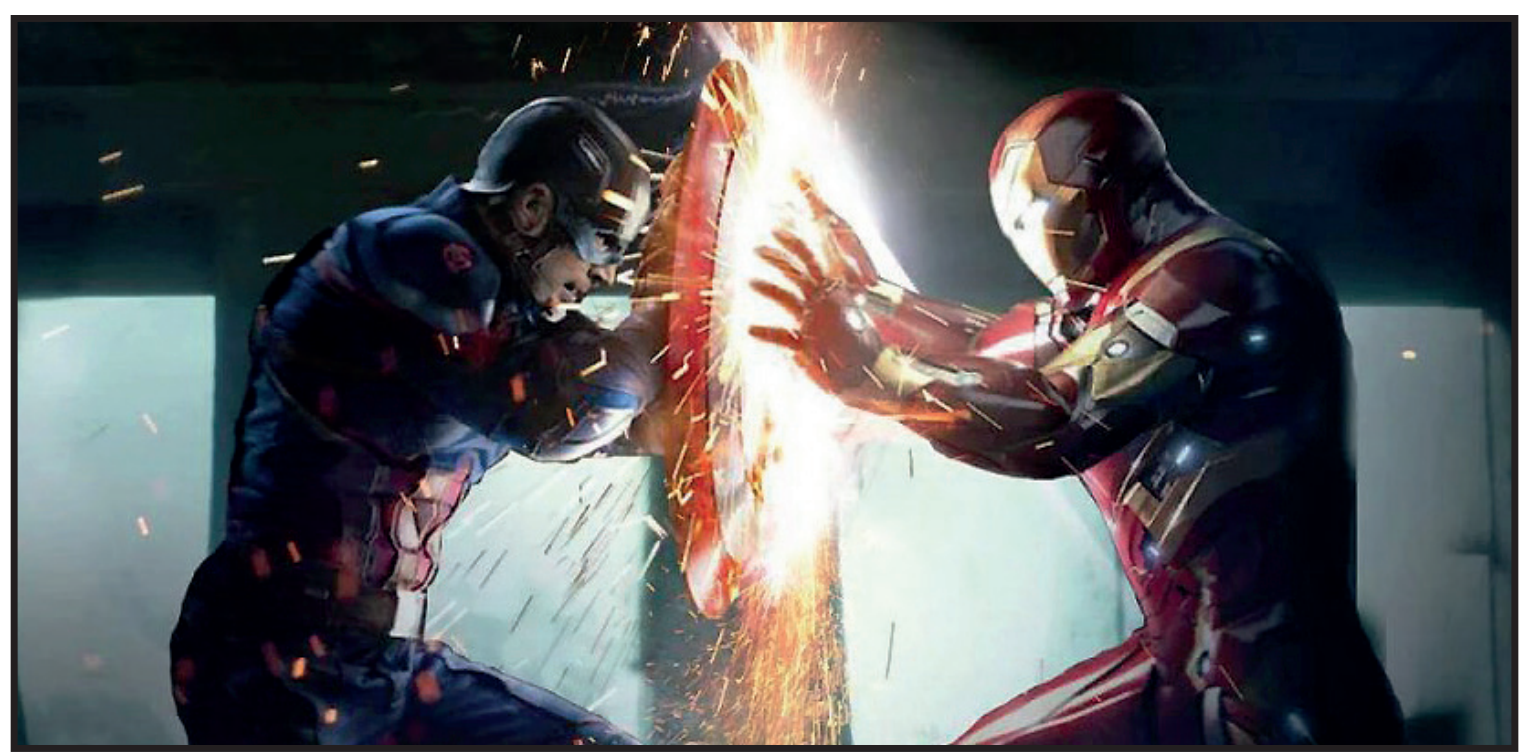

FIG. 3. Capitán América: Civil War (Captain America: Civil War. Joe \& Anthony Russo, 2016).

Elisa McCausand: Estoy un poco de acuerdo contigo. Sin ir más lejos, a propósito de todas las producciones para cine y televisión que citas, los atrevimientos formales en Deadpool no pasan de los títulos de crédito; en Agente Carter, lo pulp nunca traspasa lo escenográfico, a no ser que llamemos pulp a unos dejes noventeros que también se perciben en Supergirl - en este caso, la presencia en el reparto de Calista Flockhart, protagonista de Ally McBeal (íd. David E. Kelley para Fox, 1997-2002), podría interpretarse como un guiño-; la realización de Daredevil ha empeorado en su segunda temporada respecto a la primera, se ha vuelto más funcional, como la de Jessica Jones desde un primer momento; de Batman v Superman: El amanecer de la justicia y Capitán América: Civil War imagino que hablaremos más adelante... En cualquier caso, estamos asistiendo a una normalización, o incluso gentrificación de la imagen superheroica, destinada a hacerla comestible sin dificultades. Algo que tiene mucho que ver con la adopción, sin importar el medio, del carácter seriado de la ficción en que nos hallamos inmersos. Ello impone unos condicionantes narrativos y representativos tales para permitir la continuidad y la familiaridad del producto, que se cae en la paradoja de que, gracias a la tecnología digital, podemos hacerlo prácticamente todo, $y$, sin embargo, la tendencia es a lo apagado o lo adusto, tanto en lo que se refiere a las paletas de colores, como a los repartos y las labores de realización y montaje. Como han señalado Matthias Stork y James Gilmore, lo digital está teniendo casi más importancia «a la hora de alardear de campañas de marketing abrumadoras que enfatizan la interactividad y el disfrute del espectador potencial». ${ }^{3}$ En este sentido, se produce un cierto contraste con lo que ocurre en el ámbito de los comic books, en los que, a mi parecer, se ha impuesto un sentido de la autoría — dibujantes y guionistas procedentes del indie o la ilustración- con el fin de darle una pátina de

\footnotetext{
${ }^{3}$ Gilmore, J. N. y Stork, M. Superhero Synergies: Comic Book Characters Go Digital. Blue Ridge Summit, Rowman \& Littlefield Publishers, 2014, p. 2.
} 
calidad al cómic de superhéroes. Aunque, en la práctica, esa autoría se limite a ser una mezcla de esteticismo cuqui, experimentación irrelevante en arcos argumentales determinados, y una cierta sumisión a las expectativas del lector, que quiere verse reflejado en esas imágenes y no retado por ellas, en la línea de esa apropiación cultural hipster que consiste en hacer tuyo lo que consumes, a costa de que pierda todo su valor de choque. Pienso en las portadas de Mike del Mundo, o el Ojo de Halcón (Marvel Comics, 2012-) de David Aja, que crean una agradable envoltura sobre lo mismo de siempre, a veces de una cierta e interesante abstracción conceptual, atractiva incluso para públicos habitualmente refractarios a los comic books.

DS: En ese sentido, podría pensarse, trasciendan o no sus resultados lo anecdótico, que en los cómics hay una mayor voluntad de estilo, una mayor sofisticación. No sabe uno qué pensar: si es que la necesidad de llegar a un gran público obliga a reducir el grado de atrevimiento de los cineastas, o si los propios implicados en la producción de películas, e incluso de gran parte de los cómics, no son conscientes de que se mueven en ámbitos expresivos - que no comunicativos, por cierto- con unas peculiaridades determinadas, más allá de las «historias», los "personajes», los iconos; y que ello obliga a una reflexión sobre cada medio en particular, y los efectos de su traducción a otros, que tienden a no practicarse.

Véase por ejemplo cuando se confunde que el cómic sea un arte secuencial con el hecho de que haya de aspirar a ser relato, que las impresiones visuales siempre se codifiquen en términos de efectividad narrativa. Me sorprende lo poco que sigue hablándose de ello a niveles popular y divulgativo, más allá del estudio académico. Más aún, la facilidad con que se equiparan las imágenes del cómic y las del cine, falsos amigos, como cuando se afirma que «leer la sinergia entre ilustraciones y palabras que se produce en una novela gráfica tiene mucho en común, dado el formato, con una película». ${ }^{4}$ Peor todavía, la inconsciencia que manifiesta un autor reputado de historietas sobre su medio cuando afirma tan tranquilo que «no me gustan los cómics en los que el único valor es visual, cuando te das cuenta de que al dibujante solo le gusta eso, dibujar, pero no cuenta ninguna historia», 5 ignorando que es de la elocuencia de las imágenes de la que emana el único valor del relato, que si este trata de imponerse con unos determinados sesgos y preceptos desde un principio, los efectos finales van a ser estériles, o absurdos, o contradictorios. Parece una obviedad que la naturaleza estática de una viñeta, y su relación con una plancha o todo un cómic, tanto a la hora de realizarse como de disfrutarse, son susceptibles de generar unos efectos perceptivos y unas inferencias muy diferentes a las que propicia una imagen en movimiento en el seno de una película, incluso cuando esa imagen puede en la actualidad framearse, «que (re)veamos y detengamos

${ }^{4}$ Copeland, T. Fletcher-Spear, K. y Jenson-Benjamin, M. «The Truth about Graphic Novels: A Format, Not a Genre», en The Alan Review, n. ${ }^{\circ}$ invierno (2005), p. 43.

${ }^{5}$ Garsan, C. «No me gustan los cómics en los que el único valor es visual: Encuentro con Paco Roca», en Culturplaza (30 de abril de 2016). Disponible online en http://valenciaplaza.com/paco-roca-no-me-gustanlos-comics-en-los-que-el-unico-valor-es-visual 
libremente las películas» ${ }^{6}$ de manera que «sus lecturas ya no se realizan solo de manera lineal y de principio a fin». ${ }^{7}$

EM: Esa falta de interés que comentas en los valores expresivos y su dialéctica es evidente. Basta con prestar atención a la venta de los enfrentamientos en pantalla este año de Batman contra Superman, o de la Guerra Civil en el ámbito Marvel, que ha sido bastante vulgar, pragmática, se ha quedado en el marketing icónico; quizás, porque nunca habíamos visto pegarse en imagen fotorrealista al hombre murciélago y al hombre de acero, o a Iron Man y al Capitán América, y bastase con la campaña de comunicación, con anunciarlo, tanto en los avances como en los propios metrajes de las películas, desustanciados de cualquier profundidad en lo que se refiere al sentido de esas confrontaciones entre superhéroes. Quizás la creatividad haya que buscarla ante todo en la estrategia publicitaria, precisa y monstruosa, obligadamente elemental, que se crea para inocular a nivel global la idea de que hay algo de relevante en la contienda entre lo que apenas se percibe sino como las marcas Batman y Superman, las marcas Capitán América y Iron Man —acordémonos de como esculturas con los símbolos de Batman, Superman y Wonder Woman han llegado a instalarse en las calles de ciudades de todo el mundo para promocionar Batman v Superman: El amanecer de la justicia-, de cara además a líneas de películas cuyas fechas de lanzamiento ya están establecidas a cuatro y cinco años vista.

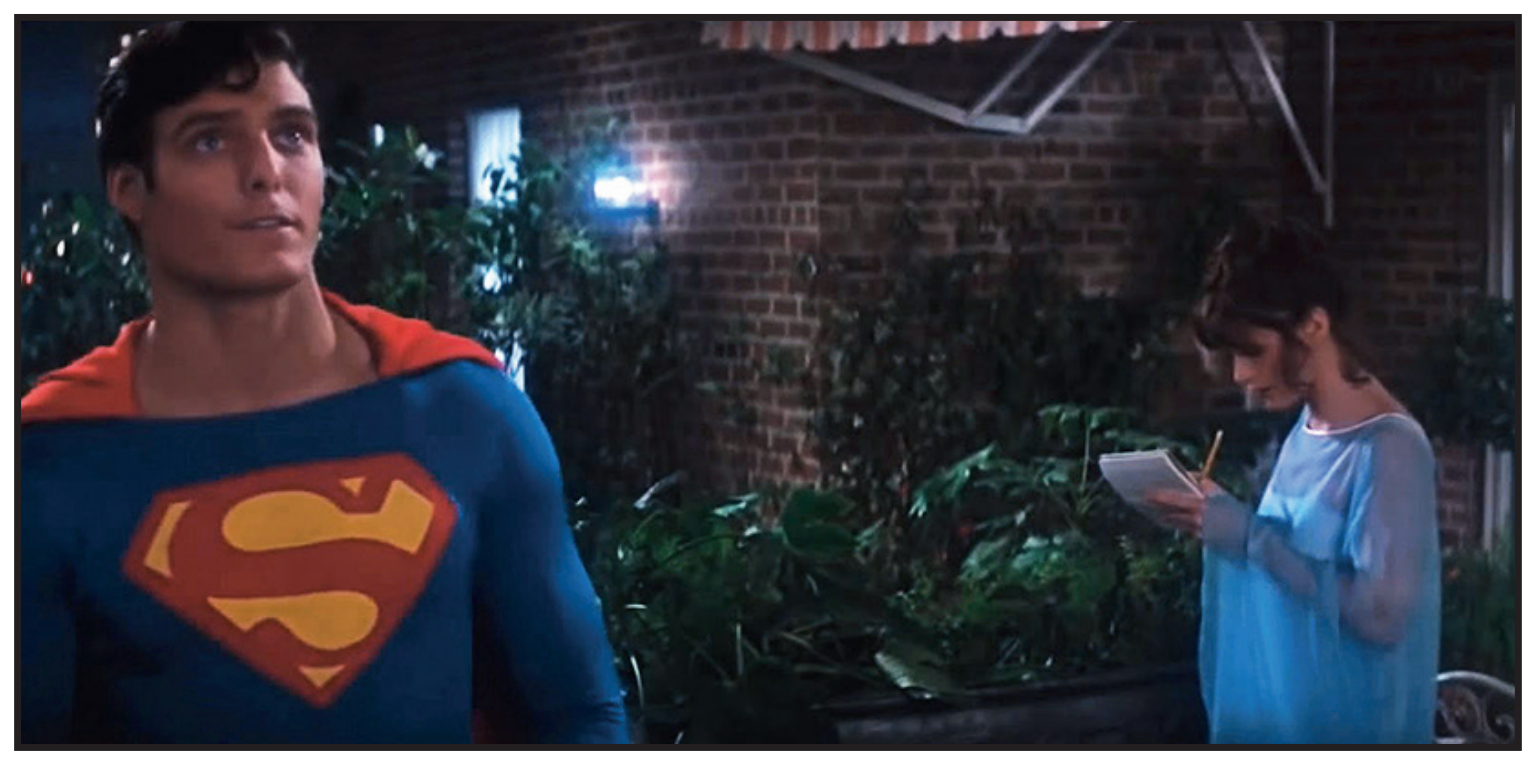

FIG. 4. Superman (íd. Richard Donner, 1978).

Más allá de la impostación de unos determinados grafismos, da igual si en los cómics o en las películas de superhéroes, estamos hablando igual de un audiovisual poco atrevido,

\footnotetext{
${ }^{6}$ SAnssoleil. «El cine y la novela en imágenes» (24 de septiembre de 2015). Disponible online en http:// www.sanssoleil.es/el-cine-y-las-novelas-en-imagenes/

7 García Sánchez-Marín, D. «The Immigrant: Sin fin», en Visual404 (8 de junio de 2015). Disponible online en http://visual404.com/2014/05/21/the-immigrant-sin-fin/
} 
lo que solo justifica en parte la influencia realista de la trilogía sobre Batman dirigida por Christopher Nolan entre 2005 y 2012, de la que hablaremos luego. Hay que tener en cuenta además, como decíamos, la gran cantidad de herramientas y medios de que se dispone hoy por hoy, y las sinergias que propicia la concepción multimedia del fenómeno: cine, cómics, televisión, videojuegos, animación, interactividad digital...

DS: No sé qué piensas, pero creo que no estamos al respecto muy lejos del Batman de Burton, o incluso se ha dado un paso atrás; es decir, lo que se dispone frente a la cámara es mucho, abigarrado, lo que reconocemos como propio de un cómic; pero lo que se hace a nivel de realización y montaje con esa iconografía y escenografía - da igual si material o virtual-, es poco, se limita a dar vida a lo preestablecido, pero no suele llevarlo más allá, no conduce a una mutación de nuestra mirada. Hablo de Batman porque, aunque las series $L a$ mujer maravilla (Wonder Woman. Douglas S. Cramer y Stanley Ralph Ross para ABC/CBS, 1975-1979), Spiderman (The Amazing Spider-Man. Alvin Boretz para CBS, 1977-1979) y La Masa (The Incredible Hulk. Kenneth Johnson para CBS/NBC, 1977-1982), y una película como Superman (íd. Richard Donner, 1978) — que dio lugar a tressecuelas y a Supergirl (íd. Jeannot Szwarc, 1984)—, ayudaron a esbozar una normalización del superhéroe en las imágenes en movimiento que escapaba a la estampa cutre del serial o al estigma pop de Batman (íd. William Dozier para ABC, 1966-1968), hasta el punto de poder hablarse de «cambio de paradigma», ${ }^{8}$ eran productos con una concepción industrial, átona, del género, a partir de los cuales se dedujo poco. En la Batman de 1989 es perceptible sin embargo una visión de connoisseur de la cultura popular, de un creador permeado por ella como Tim Burton, cuyo ánimo gótico y manierista teñiría de hecho todo lo realizado en el mismo registro a lo largo de la década de los noventa, en paralelo a otro tipo de apuestas formales, o solo estéticas, muy interesantes, hasta en películas tan fallidas como Tank Girl (íd. Rachel Talalay, 1995), Barb Wire (íd. David Hogan, 1996) — con esos alucinantes títulos de crédito en los que se subraya hasta lo obsceno el carácter pinapero de la heroína mainstream-o Rocketeer (The Rocketeer. Joe Johnston, 1991) — cuyo director lo sería también de una de las películas contemporáneas de superhéroes más bonitas para mí en varios aspectos, Capitán América: El primer vengador (Captain America: The First Avenger. Joe Johnston, 2011)-. Se da la paradoja de que las propuestas eran regulares, pero sus fotogramas resultaban vistosos, muy estimulantes. No en el sentido de «parecer un tebeo», de ser «un comic book en imágenes», como se suele decir en términos positivos, aunque solo sirva para elevar a los altares películas tan mediocres como Blade II (íd. Guillermo del Toro, 2002) frente a su predecesora, la elegante Blade (íd. Stephen Norrington, 1998); sino de innovar en el seno de la propia imagen cinematográfica. Algo a lo que no son ajenas por otra parte las influencias de medios con predicamento por entonces como la publicidad o los videoclips, o una hibridación de las imágenes con la música pop, como pasa en El cuervo (The Crow. Alex Proyas, 1994) o Batman Forever (íd. Joel Schumacher, 1995). Rarezas previas aparte, como Howard el pato (Howard the Duck. Willard Huyck, 1986), que se debe a un imaginario argumental y de efectos visuales ochentero, nos topamos con películas de una estética sombría, entendido esto desde lo manierista, no lo literal, como Darkman (íd. Sam Raimi, 1990), la trilogía

${ }^{8}$ Alarcón, T. L. Superhéroes: Del comic al cine. Madrid, Calamar Ediciones, 2011, p. 12. 
sobre las Tortugas Ninja (1990-1993), la citada El cuervo, La sombra (The Shadow. Russell Mulcahy, 1994), Juez Dredd (Judge Dredd. Danny Cannon, 1995), El hombre enmascarado (The Phantom. Simon Wincer, 1996), Spawn (íd. Mark A.Z. Dippé, 1997) —apuesta fuerte y fracasada de un director que, significativamente, se inició en el campo de los efectos visuales y ha acabado dirigiendo animación-, y las películas sobre Batman dirigidas por Joel Schumacher en 1995 y 1997, a pesar de su creencia en que un villano de cómic ha de ser trasplantado a las imágenes tal cual, lo que solo generó monstruos histriónicos.

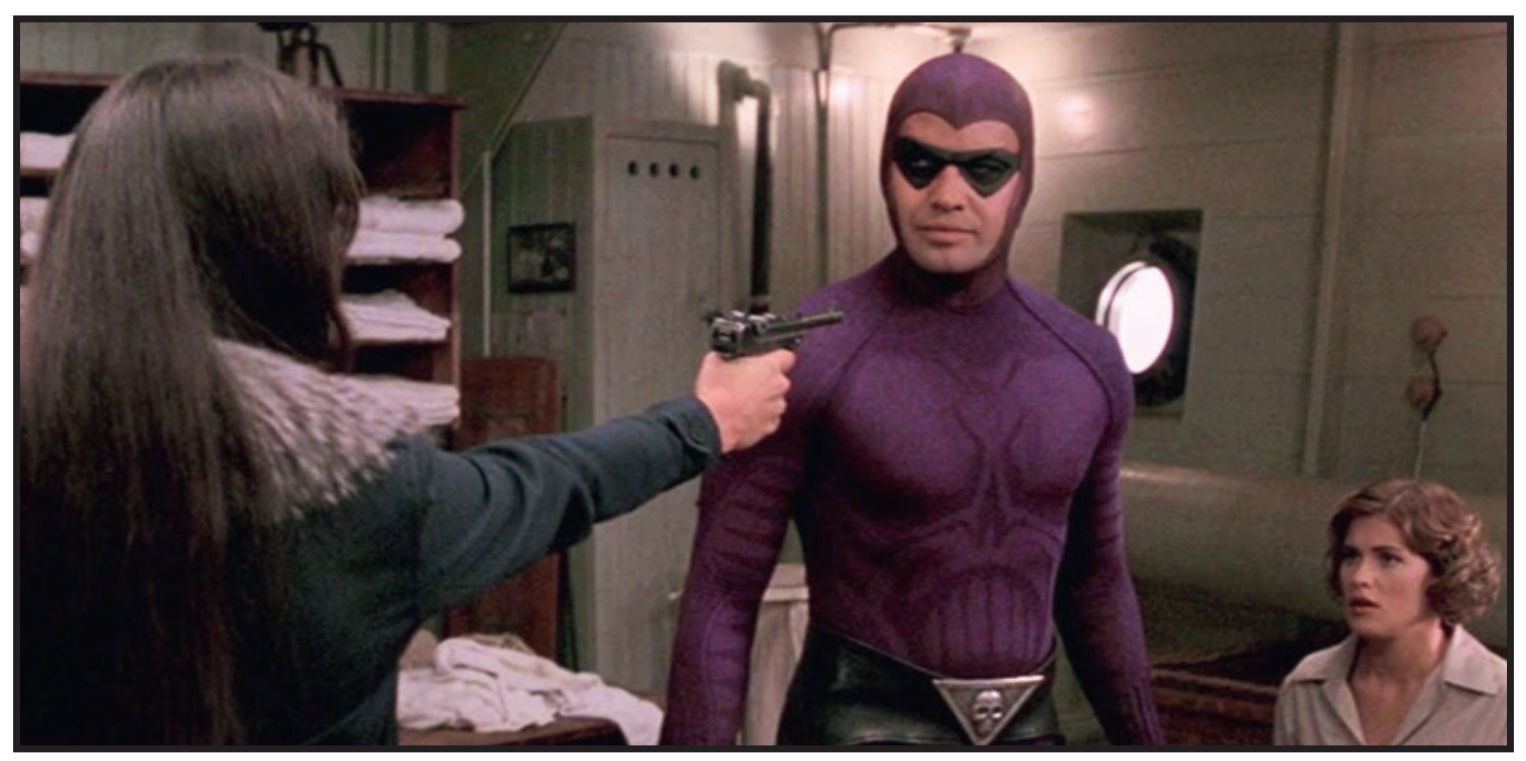

FIG. 5. El hombre enmascarado (The Phantom. Simon Wincer, 1996).

EM: El caso de El hombre enmascarado es muy interesante, porque en su momento se habló mucho de su paleta de colores — un señor vestido de morado en mitad de la jungla- $-\mathrm{y}$, además, en contraposición por ejemplo al Batman ideado por Schumacher — que, a pesar de todos sus excesos cromáticos, era nocturno- era una película que apostaba por lo diurno, lo luminoso, lógico por otra parte dado que cabalgaba en la estela del cine de aventuras que había reanimado Indiana Jones. Su intérprete, Billy Zane, también incidía en ello: «E1 personaje creado por Lee Falk no es oscuro, no está jodido: es como un caballero zen que cabalga, vestido de morado, un caballo blanco, que se rodea de otros amigos animales, y que lucha contra la piratería, la avaricia y la crueldad; hace que ser bueno parezca cool». ${ }^{9}$ Pero el color, la luz, el locurón, serían cualidades consideradas en breve defectos, como si deslegitimaran la posible seriedad en una película de superhéroes. Esa ruptura con el divertimento colorista la apuntan ya la estética impuesta por Matrix (The Matrix. Lilly / Andy y Lana / Larry Wachowski, 1999), perceptible también en $X$-Men (íd. Bryan Singer, 2000) —que los New X-Men de Grant Morrison heredan, sin que ello suponga renunciar a una autoría real sobre su cómic, es un caso de apropiación creativa enriquecedora-, y el cómic blockbuster e hiperrealista que ejemplifican The Authority (Wildstorm/DC Comics, 1999-2010) de

${ }_{9}$ Hughes, D. Comic Book Movies. Londres, Virgin Films / Random House, 2007, p. 115. 
Warren Ellis y Bryan Hitch, o The Ultimates (Marvel Comics, 2002-2004) de Mark Millar y, de nuevo, Bryan Hitch; muy interesantes, por cuanto beben del cine de gran espectáculo y lo superan en cuanto a amplitud de marco, violencia, argumentos adultos, aunque al precio de provocar que, poco a poco, el comic book vaya a remolque del cine en términos retóricos, abdique de cualidades semánticas propias.

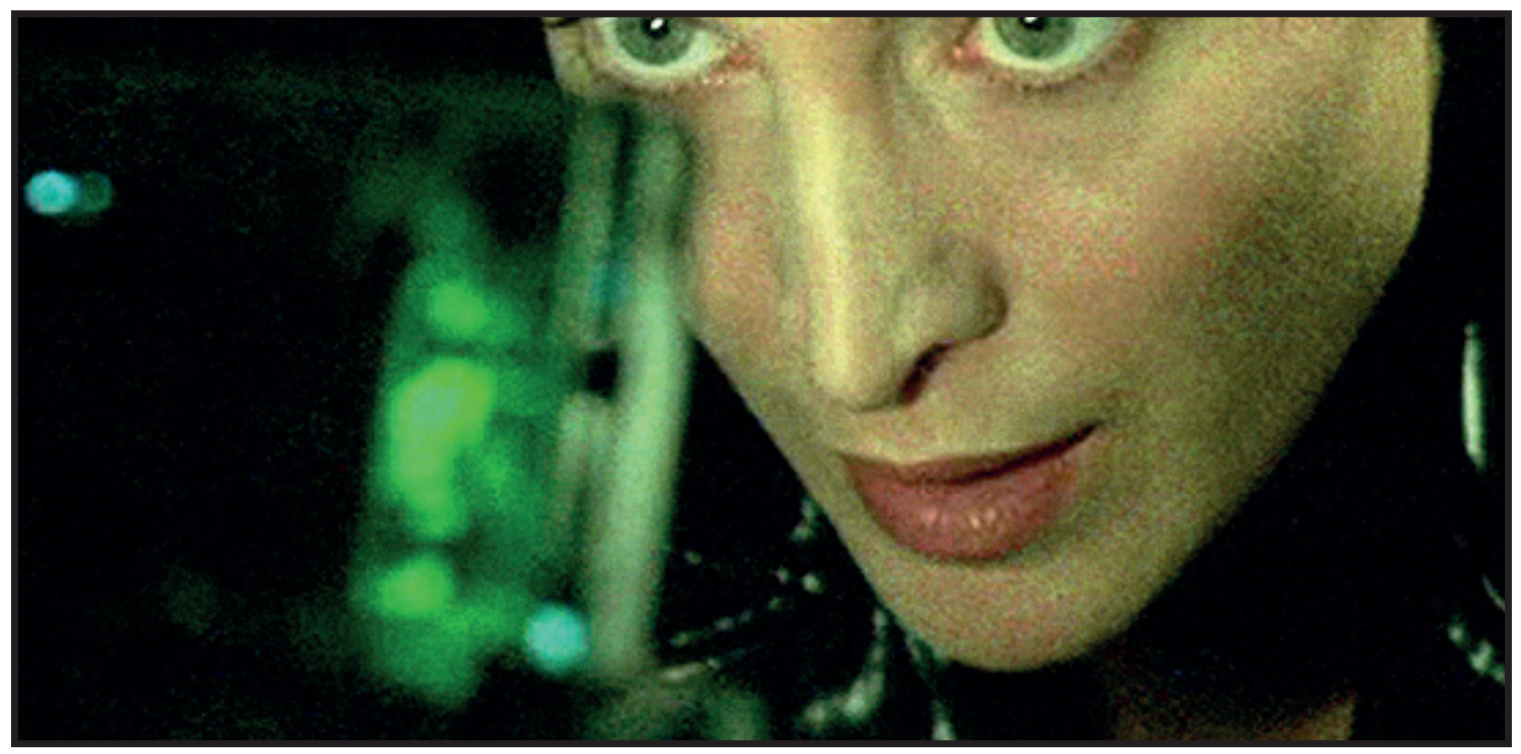

FIG. 6. Matrix (The Matrix. Lana / Larry \& Lilly / Andy Wachowski, 1999).

DS: Tú me has comentado en varias ocasiones que, a fecha de hoy, todo en la editorial Marvel, desde las líneas argumentales, a la apariencia de sus héroes y heroínas, está bastante supeditado a lo que están haciendo y puedan hacer en un futuro las imágenes en movimiento producidas por Marvel Studios. Y esto es inquietante por cuanto Kevin Feige se ha podido permitir, por ejemplo, en Capitán América: Civil War meter la Guerra Civil (Marvel Comics, 2006) ideada por Mark Millar y Steven McNiven, desustanciándola de todo lo que quiso decir en su momento - post 11-S, «Patriot Act», etc. - sin aportar a cambio nada verdaderamente significativo, cuando en su momento las estrategias visuales del cómic, como las de Bryan Hitch o John Cassaday en otros títulos, tenían un sentido: la elongación de los tiempos del relato, su misma detención, que pusieron de moda en el cine el anime y la imagen virtual -el bullet time de Matrix, los recorridos imposibles de la cámara en El club de la lucha (Fight Club. David Fincher, 1999) - servían al propósito de ejercer una crítica sobre el sentido, la marcha ideológica de ese relato, que años después ha degenerado en lo contrario: el afán de contar sin saber a qué propósito responde, porque la fiesta debe continuar, como sucede funcionalmente en Capitán América: Civil War. Aquí quizás convendría reivindicar $V$ de Vendetta ( $V$ for Vendetta. James McTeigue, 2005), muy denostada cuando se estrenó por «traicionar» el espíritu del cómic de Alan Moore y Dave Gibbons creado entre 1988-89, pero que supo reformular el anarquismo individualista del que hacían gala Moore y Gibbons en términos de conciencia colectiva contra un complejo opresor político-mediático; algo que dio cuenta, tanto de las inquietudes artísticas de las hoy hermanas Wachowski, como 
del auge de los movimientos sociales que se produciría con el cambio de década en localizaciones diversas: el 11-M, Occupy Wall Street, la Primavera Árabe...

ES: Es que, además, $V$ de Vendetta, como Superman Returns o incluso en cierta manera Batman Begins, eran partícipes de un discurso de esperanza tras el túnel del 11-S en el superhéroe, que en el cómic ejemplificó el All Star Superman (DC Comics, 2005-2008) de Grant Morrison y Frank Quitely, que la crisis se llevó por delante; hasta el punto de que deberíamos preguntarnos si el superhéroe no lo es hoy solamente por convención, dado que no hay nada en su figura que lo haga significativo de facto, como de hecho se atrevieron a enunciar tanto Superman Returns (íd. Bryan Singer, 2006) como El hombre de acero (Man of Steel. Zack Snyder, 2013). Vista así, la fiesta Civil War que mencionabas, como sucede también en Batman v Superman: El amanecer de la justicia, pasa a ser todavía más aburrida y desustanciada, solo apta para un público casi tan infantilizado y lastrado por los traumas como las criaturas de ficción. ${ }^{10}$ Las aristas de cualquier tipo brillan por su ausencia, también en otros aspectos, el sensual o el nietzscheano: no hay nada parecido a lo que pudieron permitirse, por ejemplo, los Batman de Schumacher, llenos de pulsiones homoeróticas. En esto también se ha ido hacia atrás. En la trilogía Spider-Man (2002-2007) de Raimi podía percibirse, aun a nivel muy normativo, una cierta calidez, como también en $X-M e n$ por lo que toca a la tortuosa relación entre Lobezno y Jean Grey; mientras que, en las dos aventuras de Spider-Man protagonizadas por Andrew Garfield en 2012 y 2014, o en las últimas entregas de los X-Men, apenas hay tensión. La faceta playboy de Tony Stark / Iron Man se ha volatilizado película a película...

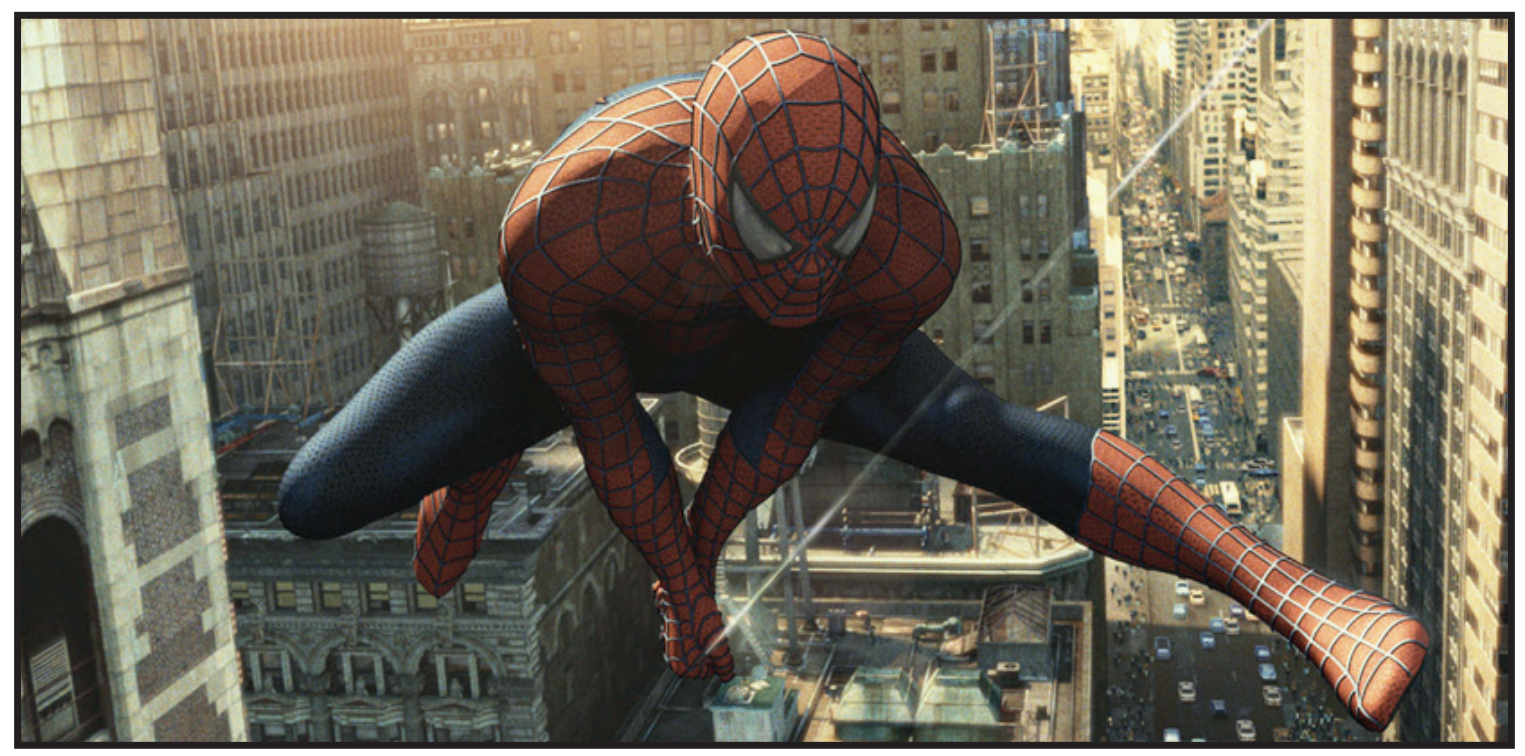

FIG. 7. Spider-Man 2 (íd. Sam Raimi, 2004).

${ }_{10}$ McCausland, E. «El superhéroe en el diván», en Periódico Diagonal, n. ${ }^{\circ} 270$ (12-25de mayo de 2016), p. 8. Disponible online en https://www.diagonalperiodico.net/culturas/30334-capitan-america-civil-war-superheroe-divan.html 
Claro que esto sucede también en los cómics: la editorial Image es la única que, de unos años a esta parte, está planteando fricciones, mientras que los «atrevimientos» de Marvel y DC pasan por la agenda de lo políticamente correcto. Resulta curioso constatar que un tema en principio tan vidrioso como el del carácter apolíneo del superhéroe, que se carnifica en el cine al estar viendo a actores muy atractivos vestidos con trajes ajustados, no da lugar en la práctica a nada mínimamente perturbador en ningún sentido. La hipermusculación uniformada de Chris Evans como el Capitán América o Chris Hemsworth como Thor no aporta nada estimulante, transgresor a las imágenes. Esto nos recuerda dolorosamente que este género, como se burlan a veces sus detractores, está dirigido a espectadores jóvenes o inmaduros, lo cual puede suponer a medio plazo un grave problema especular para que sus imágenes sean capaces de decir algo, de que maduren.

DS: Ya que has citado las películas sobre Spider-Man realizadas por Sam Raimi, para mí la primera de ellas es fundamental como definidora del cine contemporáneo de superhéroes, junto a $X$-Men o El protegido (Unbreakable. M. Night Shyamalan, 2000). Desde luego, mucho más que Hulk (íd. Ang Lee, 2003), a la que se ha dado siempre en mi opinión más pábulo del que merecía por venir realizada por un director «de prestigio», cuando la dialéctica en sus imágenes entre semiosferas fuese epidérmica; pensándolo bien, la única aportación indiscutible de Hulk en sus sucesivas apariciones cinematográficas ha sido el constituirse en banco de pruebas digital para la consecución de un monstruo con expresiones humanas convincentes. Spider-Man es una producción muy ambiciosa, plenamente comprensiva del personaje, con una mirada sobre él por parte de Raimi tan freak como la de Burton sobre Batman. Peter Parker es materializado con éxito como un ser humano que ha de lidiar con la madurez y con superpoderes, y juegan un papel esencial un aluvión de efectos visuales que, lejos de ilustrar, sirven para llevar la efigie del superhéroe a otros terrenos, como evidencian esas declaraciones de Raimi en torno a que deseaba ver al hombre araña trazando «un ballet en el cielo». ${ }^{11}$ Por otra parte, Raimi inocula en Spider-Man constantes de otros géneros que le son familiares, en especial el terror, que ya había teñido a su vez de atributos superheroicos algunas de sus películas previas, véanse Terrorificamente muertos (Evil Dead 2. Sam Raimi, 1987) y Darkman. Esto para mí es muy interesante de cara al futuro, porque uno de los potenciales más claros del cine de superhéroes no es solo el de instituirse género eterno en el imaginario popular, como antaño el western o el cine de piratas, sino dialogar con estos y ejercer como mutágeno a largo plazo de sus constantes, como han apostado por hacer ya con buenos resultados, en mi opinión, El caballero oscuro (The Dark Knight. Christopher Nolan, 2008) o Capitán América: El soldado de invierno (Captain America: The Winter Soldier. Joe \& Anthony Russo, 2014), reformulaciones respectivas del thriller urbano y el conspiranoico. Hay que reivindicar en esa línea títulos tan curiosos como Sky High, una escuela de altos vuelos (Sky High. Mike Mitchell, 2005), comedia de instituto en un mundo donde los superhéroes son moneda corriente, o Mi super ex-novia (My Super Ex-Girlfriend. Ivan Reitman, 2006), un Sexo en Nueva York (Sex and the City. Darren Star, 1998-2004) con superheroína psicótica...

${ }_{11}$ Braund, S. y Hewitt, C. «Spider-Man», en Empire, n. o de julio (2002), pp. 58-62. 


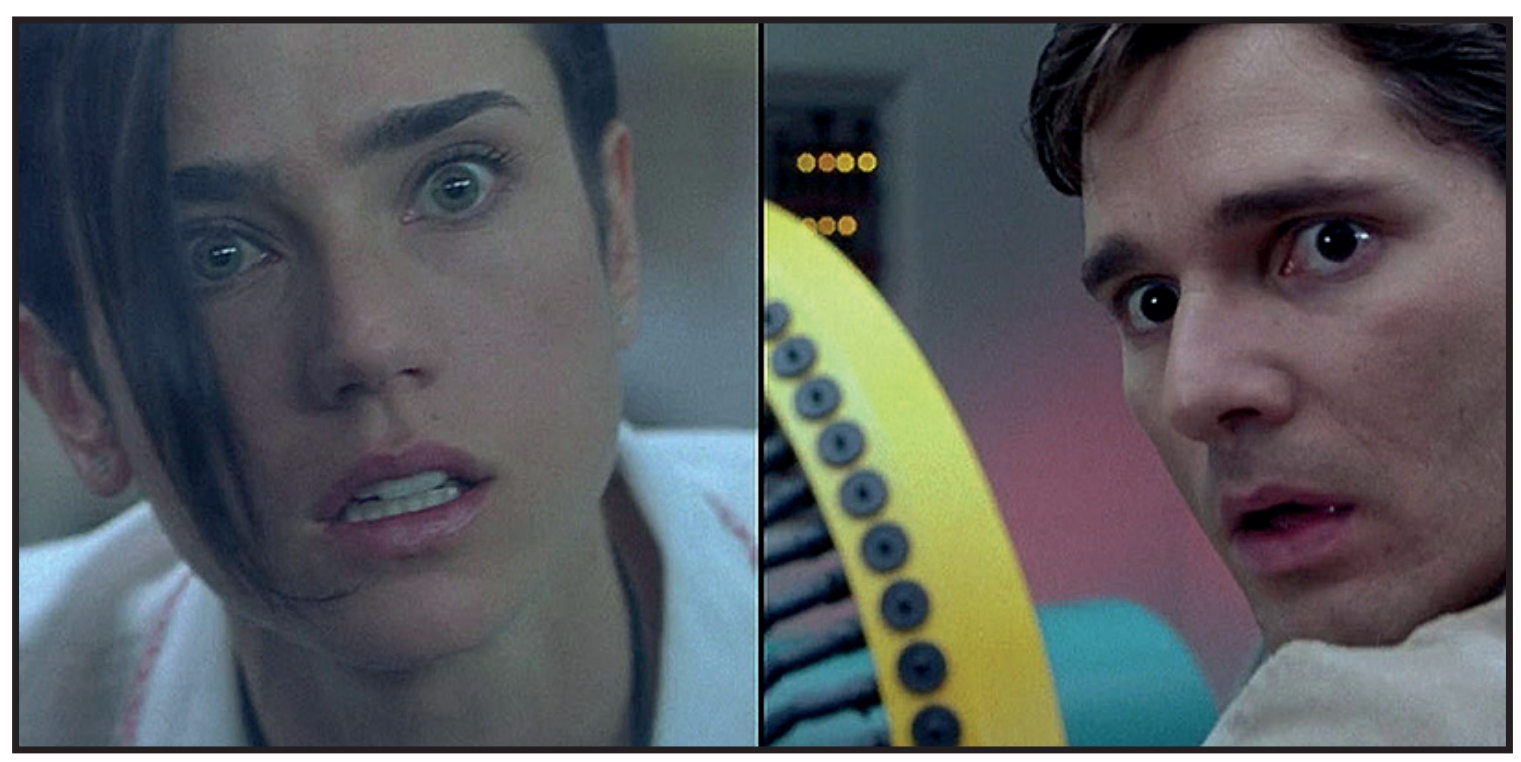

FIG. 8. Hulk (íd. Ang Lee, 2003).

EM: En ciertos aspectos, lo que has apuntado de Spider-Man se puede aplicar también a $X-M e n$, obra de un Bryan Singer que es un true believer en lo que está contando, por lo que, pese al ajustado presupuesto de la película, hay una convicción total en lo que se nos muestra, además de apreciarse para bien la influencia de un Chris Claremont fundamental para la redefinición en los cómics de los mutantes. Aunque algunos se enfadasen, porque cada uno tiene sus propios X-Men en la cabeza, el debate creado en torno a ello daba muestras saludables de que había una comunidad friki en desarrollo, consciente de sus propias posibilidades e influencia, en buena medida gracias a la existencia de Internet. Y todo esto va más en la siguiente entrega, $X$-Men 2 (X2. Bryan Singer, 2003) que, no solo hacía creíble la idea de una película superheroica para todos los públicos, sino que, además, en mucho mayor grado que $X$-Men, permitía que fuesen verosímiles la presencia y la interacción dramática entre varios superhéroes, sin que ello fuese ridículo. Quizás eso también trajo consigo —es algo que solo puede contemplarse con perspectiva - un germen de mediocridad visual, de apuesta por un folletín de plano medio en el que parece que se suceden muchos acontecimientos aunque en realidad no pase nada, de un clasicismo en la puesta en escena para que suceda el melodrama; una estrategia propia de un Bryan Singer que ha dejado de lado hasta la fecha, por ejemplo, las imágenes que podrían surgir de representar en pantalla la Sala de Peligro o los pensamientos y alteraciones de la realidad provocados por las mentes telépatas. Un tipo de escenas que, en el ámbito del gran espectáculo, yo solo recuerdo haber visto a lo largo de este siglo en Piratas del Caribe: En el fin del mundo (Pirates of the Caribbean: At World's End. Gore Verbinsky, 2007), cuando Jack Sparrow es atrapado por Davy Jones en una dimensión alternativa, y que cabe confiar en que jueguen un papel en Doctor Extraño (Doctor Strange. Scott Derrickson, 2016). Esa normatividad expositiva de Singer la he percibido también en Superman Returns, en la que hay mucho de representación, de teatral, en parte por homenajear el espíritu de Richard Donner para la Superman de 1978. Ahí está el Lex Luthor que encarna Kevin Spacey, enésimo ejemplo por cierto de actor de prestigio 
metido a interpretar villanos o papeles secundarios en una película popular, con el objetivo de legitimar sus imágenes, una estrategia que institucionalizaría La guerra de las galaxias (Star Wars. George Lucas, 1977).

Durante la era del blockbuster, en pocas ocasiones se ha dado al respecto una semántica más profunda, más significativa, capaz de revolucionar el sentido del superhéroe desde la esencia. Aunque, ya que hablamos de películas fundamentales de entresiglos, M. Night Shyamalan sí logró hacerlo al convertir en El protegido a un héroe de acción como Bruce Willis en un arquetipo apolíneo del Bien, enfrentado a un arquetipo contrahecho del Mal, el Mr. Glass interpretado por Samuel L. Jackson, que, de una manera casi visionaria dada la proximidad del 11-S — la película se estrenó en todo el mundo a caballo entre los años 2000 y 2001-, provocaba atentados para que el superhéroe que llevaba dentro David Dunn (Willis) se manifestase. Como sabemos, la redefinición del héroe es una constante de la cultura popular posterior a lo sucedido el 11 de septiembre de 2001.

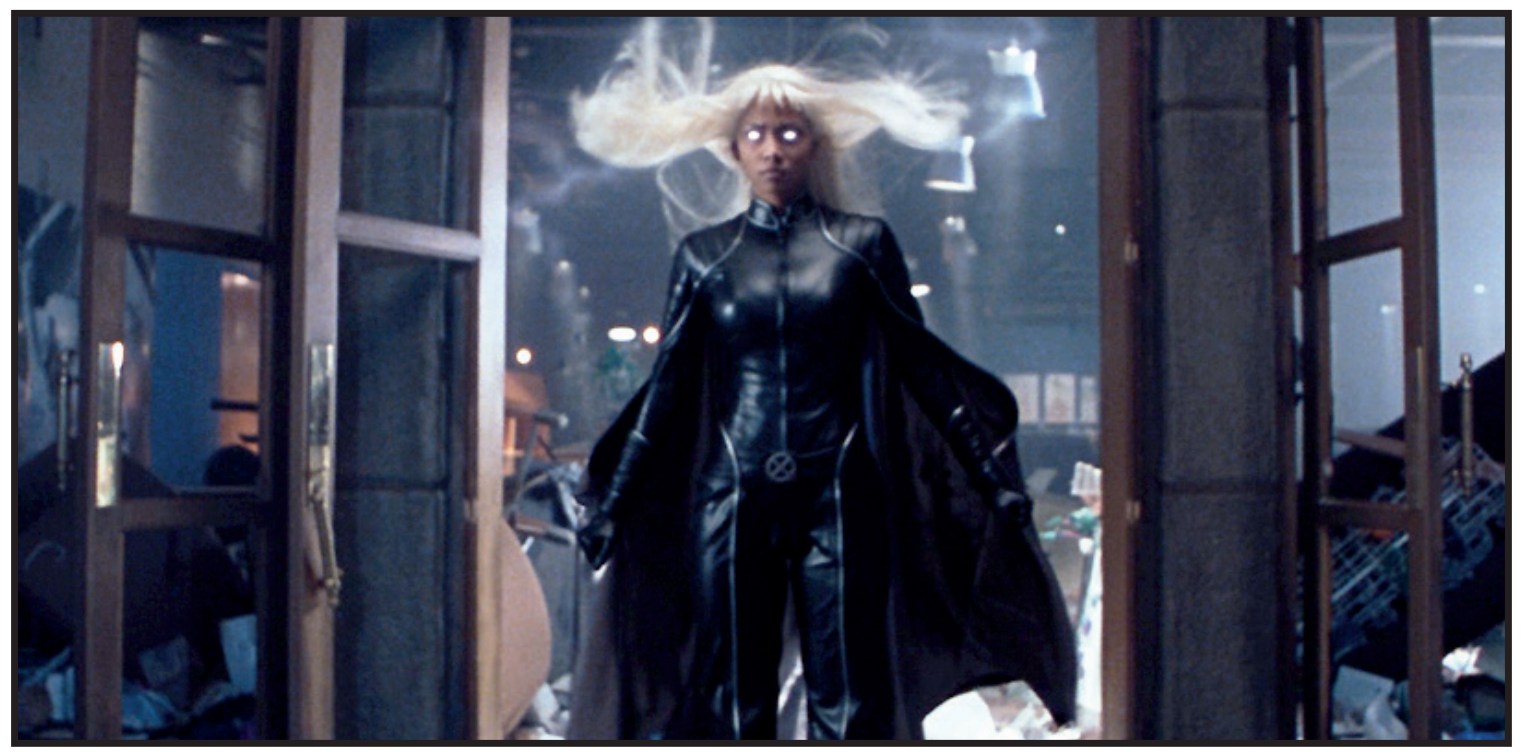

FIG. 9. X-Men (íd. Bryan Singer, 2000).

DS: El protegido es un título que no deja de crecer con el tiempo. Siempre se cita como prototipo de película de superhéroes de autor la trilogía sobre Batman de Christopher Nolan, pero, para mí, El protegido es mucho más ambiciosa y de obligada referencia: Shyamalan habla no del superhéroe, sino del comic book de superhéroes, del medio y el formato y, como ha apuntado A. J. Regalado, «de las tensiones sociales implícitas en la apreciación de los comic books, en el tradicional estatus marginal que los mismos y sus fans han tenido en la sociedad norteamericana». ${ }^{12}$ Yo añadiría que también habla de la belleza de una historieta mensual de veintidós páginas y grapa, de su poder transformador de la realidad, de la filosofía de lectura y existencial presente en el disfrute de ese medio, de la alienación peligrosa que puede con-

12 Regalado, A. J. «Unbreakable and the limits of transgression», en Gordon, I. , Jancovich, M. y McALLister, M. P. (eds.) Film and Comic Books, Jackson, University Press of Mississippi, 2007, p. 117. 
llevar y, también, de su gentrificación, su elevación como ocurre hoy a parámetros culturales más dignos, con el riesgo de pulcritud y desarme latente en ello... y todo ello a través de un relato cinematográfico plagado de virtudes. Por otra parte, su relato pone en evidencia, a lo largo de su desarrollo y mediante su golpe de efecto final, que la aventura del superhéroe precisa del villano para tener un sentido, y que la conciencia de ello puede desembocar en una grave crisis de identidad. Todo ello gracias, insisto, a un aparato formal deslumbrante, en el que, con cero elementos escenográficos, se plantea con mucho talento el contraste entre una mirada cotidiana sobre lo real y la que deriva de ostentar unos poderes especiales. Y sin olvidar el argumento de fondo presente en todo el cine de Shyamalan, perfectamente imbricado en el argumento concreto de El protegido, que es el de creer, creer en aquello en que te han inmerso las circunstancias para dar lo mejor de ti mismo y salvarte. Dieciséis años después, casi nadie ha ahondado en todo esto, salvo quizás de una manera primaria Watchmen (íd. Zack Snyder, 2009); Super (íd. James Gunn, 2010), una de las pocas obras maestras del género hasta la fecha, desde luego una de las más reflexivas, que vale la pena recomendar siempre que uno tiene ocasión; y Chronicle (íd. Josh Trank, 2012), una película cuyo dispositivo formal, el recurso al found footage — que en su caso valdría calificar más de imagen en directo-, albergaba toda una metáfora de alcance meta y casi nietzscheano en torno a la posibilidad de que el superhéroe pueda o no ejercer poder sobre su propia imagen, o si va a ser siempre sumiso a lo que disponga en torno a él la realidad audiovisual consensuada.

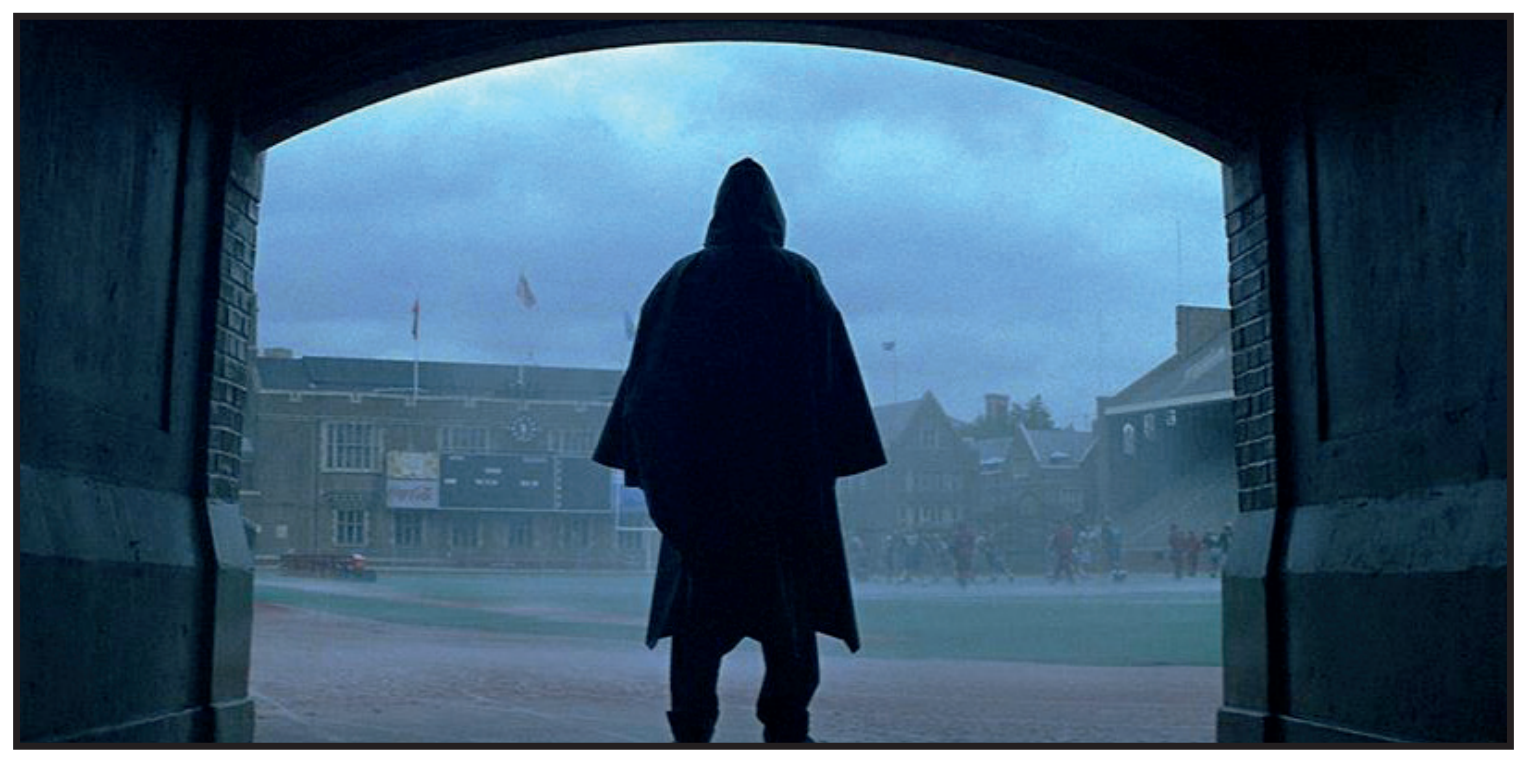

FIG. 10. El protegido (Unbreakable. M. Night

Shyamalan, 2000).

EM: En cualquier caso, desde aquellas películas — Spider-Man, El protegido, X-Men- hasta hoy, es obvio que el factor más sonado, que no sé si significativo, han sido Batman Begins (2005), - sobre todo- El caballero oscuro, y El caballero oscuro renace (2012); proclama las tres de la mano de Christopher Nolan de una madurez del género, de una entrada en la edad adulta, que ha quedado más bien como excepción, por no hablar de la aplicación errónea de su realismo y su gravedad cuando no tocaba o siendo malinterpretadas. Lo cierto es que 
cuando se estrenó Batman Begins todavía era posible que lo hicieran casi al mismo tiempo Catwoman (íd. Pitof, 2004) - la demostración, todo sea dicho, de que la libertad absoluta en cuanto a los efectos visuales y la inventiva de la cámara pueden desembocar en una catástrofe-, o Los cuatro fantásticos (Fantastic Four. Tim Story, 2005) - una película jovial, sin demasiadas aspiraciones, que funcionaba en sus propios términos, amén de plantear un discurso interesante sobre lo que significa ser un superhéroe en la era de lo mediático-. Batman Begins, por el contrario, es una película típica de Nolan: hiperinflación de ideas y discursos, a veces desde luego muy pertinentes y de mucho interés, abordados con una supuesta trascendencia algo impostada, carencias formales para traducirlos en imágenes de una manera orgánica, y muy poco sentido de la fantasía y la maravilla, como demostraría después el que una nunca haya visto un universo de los sueños más mecánico y poco estimulante que el plasmado en Origen (Inception. Christopher Nolan, 2012), un manual de instrucciones sobre lo onírico. El resultado es que lo mejor de su trilogía sobre Batman son para mí las líneas de fuga y, en especial, el Joker interpretado por Heath Ledger en $E l$ caballero oscuro, cuyo impacto se le fue claramente de las manos a Nolan; el Joker era un tumor, mientras que todo lo demás es algo benigno, empezando por un Batman que nunca ha encontrado su sitio en esas tres películas. Hay otros argumentos, aunque apenas otra cosa que enunciados o descritos: El caballero oscuro, por ejemplo, se sitúa en un momento clave, el post 11-S y el comienzo de la crisis. Por desgracia, al menos para mí, Nolan ha tenido un profundo calado entre el fandom sustanciado en una gentrificación de lo que debe ser el superhéroe, un carácter adulto muy entre comillas, que ha venido bien para darle legitimidad pública a la cultura popular y al mercado asociado, un fenómeno esencial de nuestra época. Todavía este año, ante el estreno de Capitán América: Civil War, algunos han echado de menos en sus imágenes una autoría como la de Nolan, cuando la misma ha sido una singularidad sin demasiadas secuelas, e, insisto, ni mucho menos redonda en sí misma.

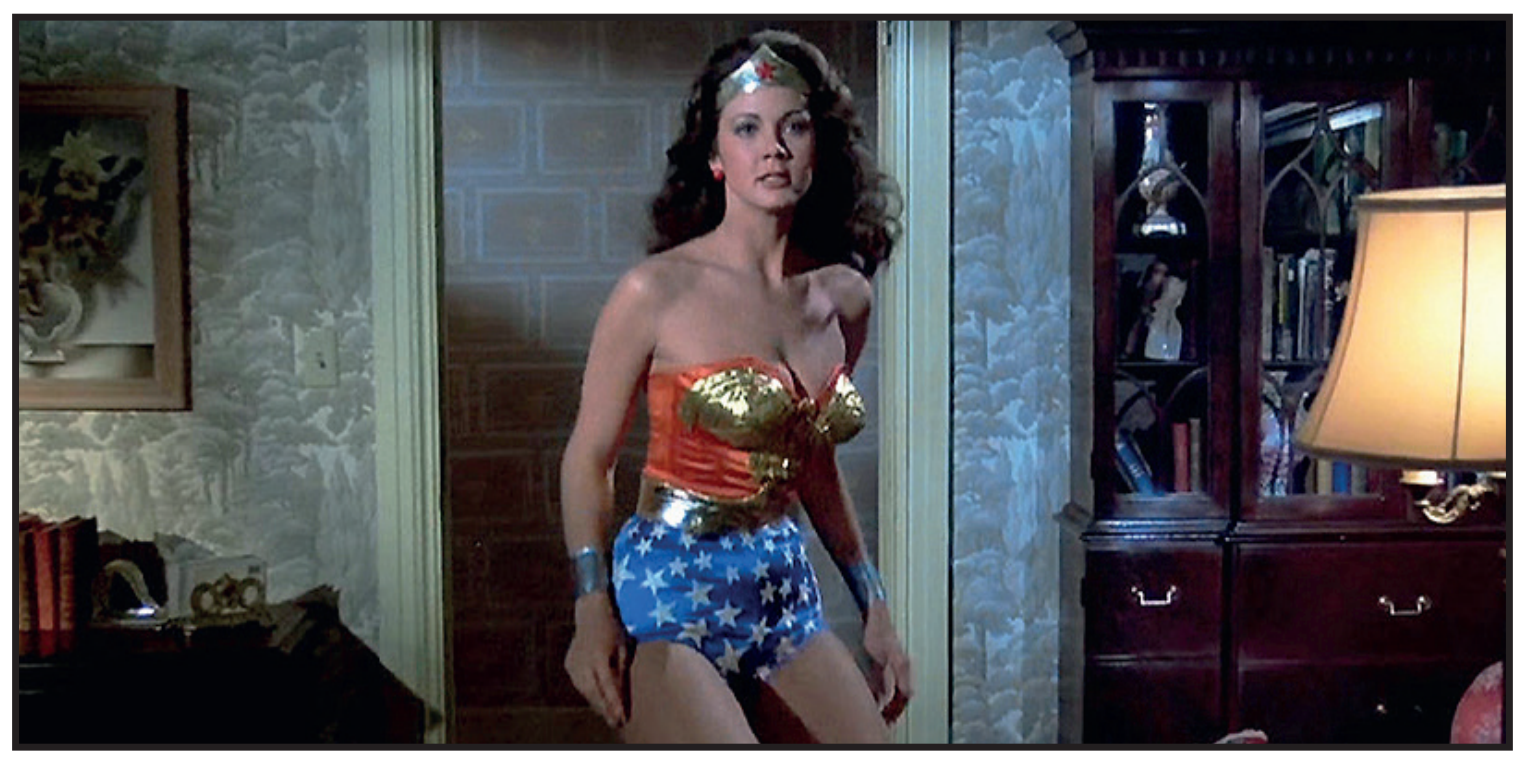

FIG. 11. La mujer maravilla (Wonder Woman. D. S. Cramer y S. R. Ross para ABC / CBS, 19751979). 
DS: Estamos en lo de siempre, la oratoria mayor o menor de las imágenes no tiene nada que ver con la profundidad de los discursos que se quieran verter en las mismas, sino con la armonía y la potencia que tengan ellas en sí para expresar lo que se pretendía, sea poco o mucho a nivel de intenciones. Es curioso que el mismo año que El caballero oscuro se estrenase Iron Man (íd. Jon Favreau, 2008), otra película acerca de un superhéroe millonario, que optaba, a diferencia de la obra de Nolan, por la línea clara, por ser una ficción más convincente en sí misma y menos preocupada por epatar en lo relativo a sus pretensiones, y que en definitiva era mucho más lograda y, encima, tenía también un discurso, sobre la naturaleza del emprendedor/empresario estadounidense en el seno del capitalismo, que continuaría en Iron Man 2 (íd. Jon Favreau, 2010) y se iría diluyendo a medida que Marvel empezase a transformarse como productora, no en una generadora de películas idiosincrásicas, autosuficientes, sino en una cadena cuasi televisiva de montaje, en la que cada título es un episodio de una serie de televisión titulada Los Vengadores. La solidez en las imágenes de Iron Man, la verosimilitud absoluta de sus efectos digitales, su entusiasmo, hacen de ella una de las obras maestras del género a siete u ocho años vista. Estéticamente, además, es una película con una textura cálida, viva, en la que no todo ha sido devorado por eso que tú denominas grisalla, la sumisión a unos grises y azules cenizos. La rendición paulatina en todo plano a los efectos digitales, a una concepción en sí misma digital de la imagen, más los requerimientos del 3D, han arrebatado a la imagen ese punto de grano, de organicidad, de color, que ha hecho aburridos todos los esfuerzos innegables en lo referido a diseños de escenarios y vestuario. En esto, veo un contraste claro con los cómics de superhéroes de hoy, que, gracias a los medios técnicos de dibujo, composición y publicación, disponen hasta el exceso de un bagaje apabullante de colores y tramas. Puede que falten talentos geniales, que los trazos sean el fruto estándar de escuelas y estudios, que se peque de hacer dibujos bonitos, pero, en cualquier caso, la diferencia con las paletas cinematográficas está ahí.

EM: De todas maneras, hablar de texturas y de su sumisión o no a una imagen digital entendida en su grado cero de riesgo y dilemas técnicos, es remitirnos a Sin City: Ciudad del pecado (íd. Frank Miller y Robert Rodriguez, 2005) y su tardía continuación, Sin City: Una dama por la que matar (Sin City: A Dame To Kill For. Frank Miller y Robert Rodriguez, 2014), 300 (íd. Zack Snyder, 2006) y The Spirit (íd. Frank Miller, 2008); en todas ellas está implicado de una y otra manera Frank Miller. Creo que ambos coincidimos en que, ni Sin City, ni su secuela, son demasiado interesantes, a pesar del fervor friki y hasta académico que despertaron, ya que la dialéctica que mantienen entre imágenes-cómic e imágenes-cine es entendida de la manera más literal, menos rigurosa posible, hasta hacer de ambas productos que nacen caducos, inertes: «A Robert Rodriguez no le preocuparon las diferencias entre el cómic y el cine, sino sus afinidades: cómo replicar las cualidades de las historietas, cómo minimizar las especificidades de un medio en su trasvase a otro. De acuerdo con las teorías de Noel Carroll sobre las artes y los marcos, la estrategia imitativa de Rodriguez tenía que fracasar a la hora de validar las expresiones únicas, precisamente las más fructíferas, de cada medio». ${ }^{13}$

${ }_{13}$ Eighan, E. E. «Sin City, Hybrid Media, and a Cognitive Narratology of Multimodality», en Aldama, F. L. (coord.) Critical Approaches to the Films of Robert Rodriguez. Austin, University of Texas Press, 2015, p. 109. 


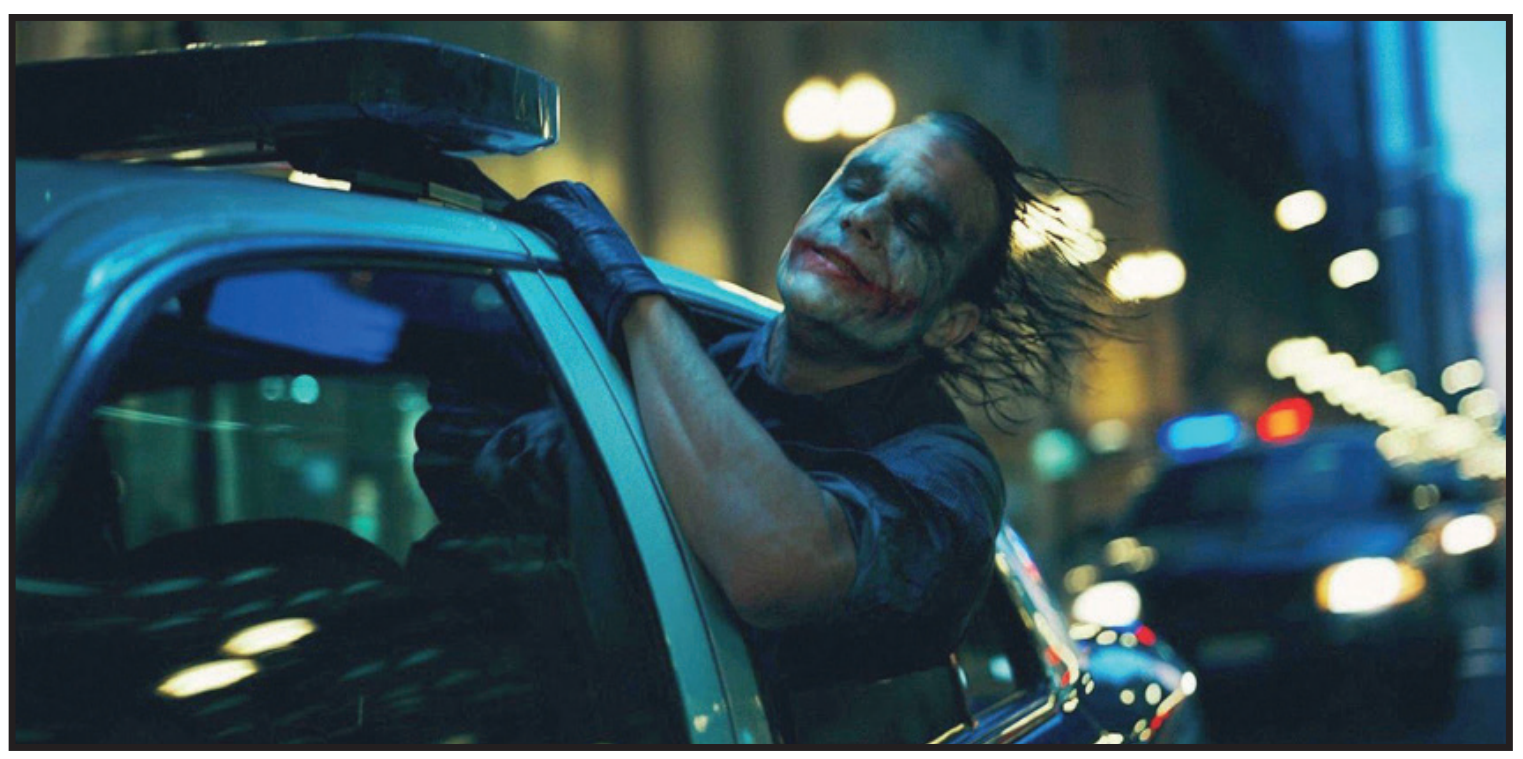

FIG. 12. El caballero oscuro (The Dark Knight.

Christopher Nolan, 2008).

Incluso aunque solo te interesase como fan ver las viñetas convertidas en fotogramas - lo que de por sí es una aberración, carece de sentido-, es que en el cómic tú gestionas los tiempos de lectura, aportas tu propio ritmo a lo que lees; mientras que, en pantalla, todo es más rápido, porque se mueve y evoluciona, y, a la vez, más aburrido, porque te ves arrastrado a que te cuenten algo, además en varias ocasiones como es el caso de Sin City, que es esencialmente estático a pesar de su movimiento aparente. La única inquietud que ofrecen las imágenes de Sin City está ligada a la presencia rotunda, cárnica, de Rosario Dawson, como la de Eva Mendes en The Spirit. Algo que da que pensar en torno a la convicción que puede o no transmitir la imagen estilizada digital, al menos mientras existan referentes físicos y estos no puedan clonarse de manera verosímil virtualmente; quizás, el creciente protagonismo de actrices tan insustanciales en la forma, de una androginia — reasignada, ojo, a género- infinitamente manipulable, como Felicity Jones, Gal Gadot, Alicia Vikander o Daisy Ridley, vaya en esa línea de diluir las fronteras entre el trazo de lo fotorrealista y el trazo de lo digital, y de no desafiar, de paso, en ningún aspecto al consumidor / consumidora.

Otra cosa es 300, en la que sí hay una tensión creativa fructífera entre las imágenes-viñeta de Miller y su reinterpretación mediante ralentís, cuerpos subrayados y efectos preciosistas; Snyder ha logrado, en palabras de Jordi Revert, «reproducir con la complicidad de los últimos avances tecnológicos la unidad de significado que supone la viñeta, y salvar las diferencias gramaticales que existen entre uno y otro medio». ${ }^{14} \mathrm{Y}$ también vale la pena detenerse en The Spirit, que dirigió el propio Miller a partir de las historietas de Will Eisner y en la estela de Sin City. Debo ser de las pocas personas a las que interesa esa película, a nivel de iconicidad y experimento, de estética... siempre que no te importe la fidelidad a la obra

${ }_{14}$ Revert, R. «La intermedialidad entre cine y cómic en la era digital: el caso Zack Snyder», en Revista Internacional de Ciencias Sociales Interdisciplinares, vol. 5, n.o 1 (2016), pp. 153-160. 
de Eisner. Samuel L. Jackson o Scarlett Johansson no eran personajes, eran ellos mismos prácticamente jugando, y ese aire de representación teatral digitalizada, paródica, de pose para colección de cromos, de sesión de fotos para una revista de tendencias con el universo Eisner como referente, me pareció curioso. Además, creo que es un síntoma creativo más a analizar de Miller en su etapa última, que también representó Batman: The Dark Knight Strikes Again (DC Comics, 2001-2002) y se discute ahora mismo a propósito de sus ilustraciones para Dark Knight III: The Master Race (DC Comics, 2016), en la que ha apostado por la locura experimental, por la distorsión grotesca, que me parece que plantea todo un reto apasionante para la imagen consensuada del superhéroe. Más cuando la norma hoy por hoy es la corrección política y lo líquido, también en las formas. El espíritu Miller clásico hay que buscarlo en las imágenes en movimiento de RoboCop 2 (íd. Irvin Kershner, 1990) o en la serie sobre Daredevil a cargo de Drew Goddard.

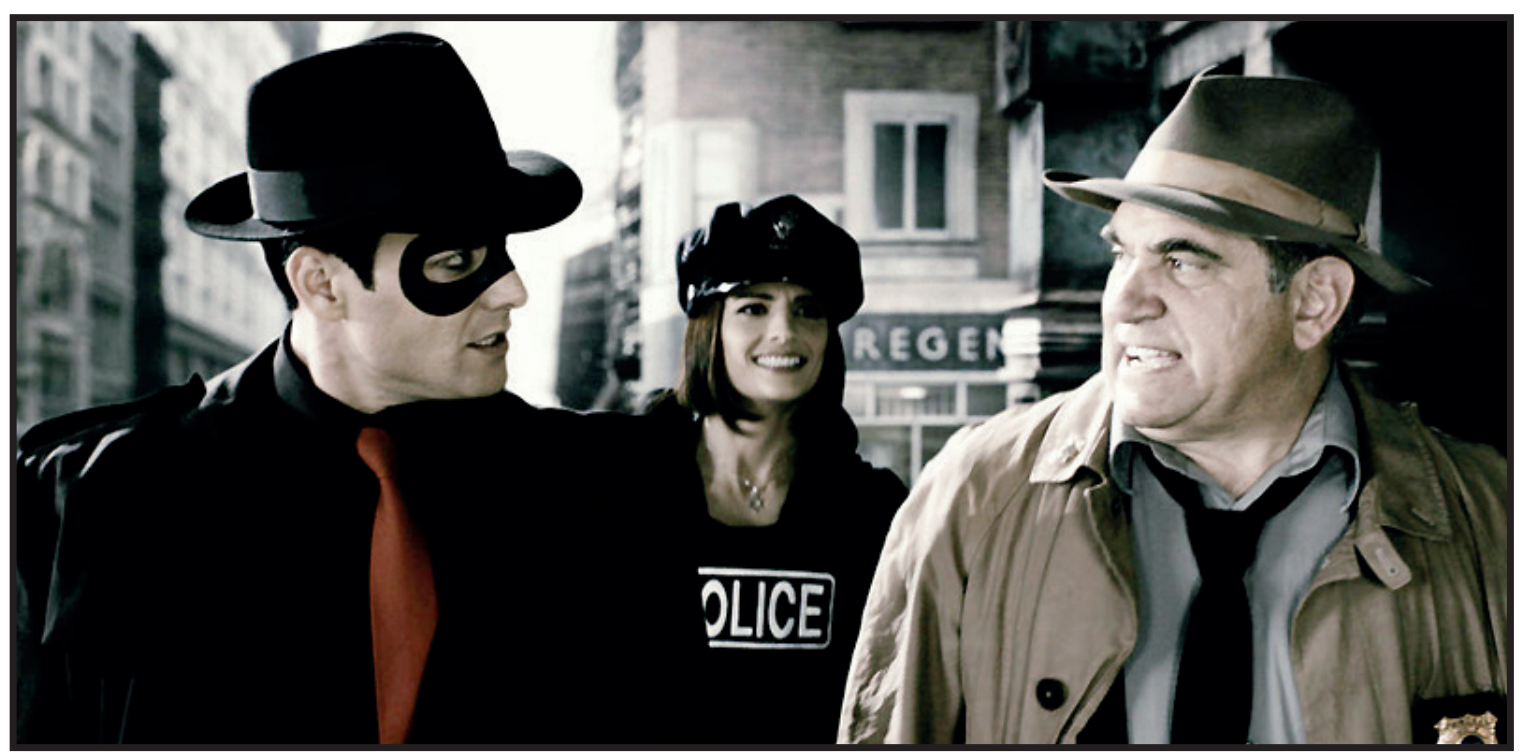

FIG. 13. The Spirit (íd. Frank Miller, 2008).

DS: Ya que nos hemos metido en rarezas o terceras vías, más allá del modelo imperante - tanto da si factoría Marvel, o los intentos convulsos de Warner/DC por instaurar un universo o canon, o todas esas series de televisión en torno a los superhéroes que, salvo excepciones muy puntuales como la protagonizada por Daredevil que acabas de citar, son meramente funcionales-, me gustaría valorar algunos títulos en dos direcciones: una, la del cine basura, títulos que, por decisión expresa de sus responsables desde un primer momento -como Ghost Rider: Espiritu de venganza (Ghost Rider: Spirit of Vengeance. Brian Taylor \& Mark Neveldine, 2011) o Ninja Turtles (Teenage Mutant Ninja Turtles. Jonathan Liebesman, 2014)-, o porque no se ha confiado en ellos durante su producción y se han concretado dentro del mainstream como una excrecencia incómoda - pienso en Kick-Ass 2 - Con un par (Kick-Ass 2. Jeff Wadlow, 2013) - , hacen ostentación en sus imágenes de una libertad exaltada que se adscribe sin complejos a lo más tirado de la cultura popular —el comic book mensual de grapa de usar y tirar, para echar una tarde-; libertad que hace posible toparse con formas inesperadas y discursos a contracorriente, incluso empoderantes; más 
que nada porque todo el mundo estaba mirando hacia otro lado mientras se gestaban, desde sus productores hasta los críticos. Es un tipo de cine que cada vez me interesa más: por un lado, no se crea en los márgenes, tiene una ventana abierta a lo comercial, lo que le procura un alcance real en el mundo, no solo en la burbuja de las tendencias culturales. Por otro, está lleno de faltas ortográficas y gramaticales susceptibles de procurar a sus grafismos pulp sentidos inéditos, o siquiera de reverdecer los que, en producciones más pendientes de su entorno, ya no son más que palabras al dictado, cacofonía. Espero que no se entienda como una boutade: entre el sentido de la maravilla, de lo chocante o lo sublime, que pueden llegar a procurar bodrios, malas hierbas, como Ghost Rider: Espiritu de venganza y Ninja Turtles, y el derivado de fantasías domésticas y fitosanitarias como Thor (íd. Kenneth Branagh, 2011), Thor: El mundo oscuro (Thor: The Dark World. Alan Taylor, 2013) y Guardianes de la Galaxia (Guardians of the Galaxy. James Gunn, 2014), no tengo ninguna duda: me parece mucho más estimulante el primero. $Y$, en otra dirección paralela, que no opuesta aunque pudiese parecerlo en un primer vistazo, situaría títulos como Blade, que creo ya he citado, Constantine (íd. Francis Lawrence, 2005), Push (íd. Paul McGuigan, 2009), Kick-Ass - Listo para machacar (Kick-Ass. Matthew Vaughn, 2010), Dredd (íd. Pete Travis, 2012), Kingsman: Servicio secreto (Kingsman: The Secret Service. Matthew Vaughn, 2014) y, a pesar de su irregularidad, Cuatro Fantásticos (Fantastic Four. Josh Trank, 2015); películas todas ellas conexas en mayor o menor medida a lo superheroico, pero, en cualquier caso, elegantes en tanto cine popular; capaces de erigirse en ficciones sugestivas y autosuficientes, sabedoras de que el espíritu de un determinado cómic es algo muy complejo que carece de sentido tratar de replicar o traducir a imágenes en movimiento, sino que requiere de una reinterpretación en tanto tales; y con potencial para propiciar todo tipo de lecturas sobre el presente en que han sido realizadas y sus propios recursos expresivos. En este sentido, me parece fundamental la labor que está llevando a cabo Matthew Vaughn con todo en contra - la crítica seria, el fandom-: su cine es pop de precisión, autorreflexivo y magnífico en su control de la

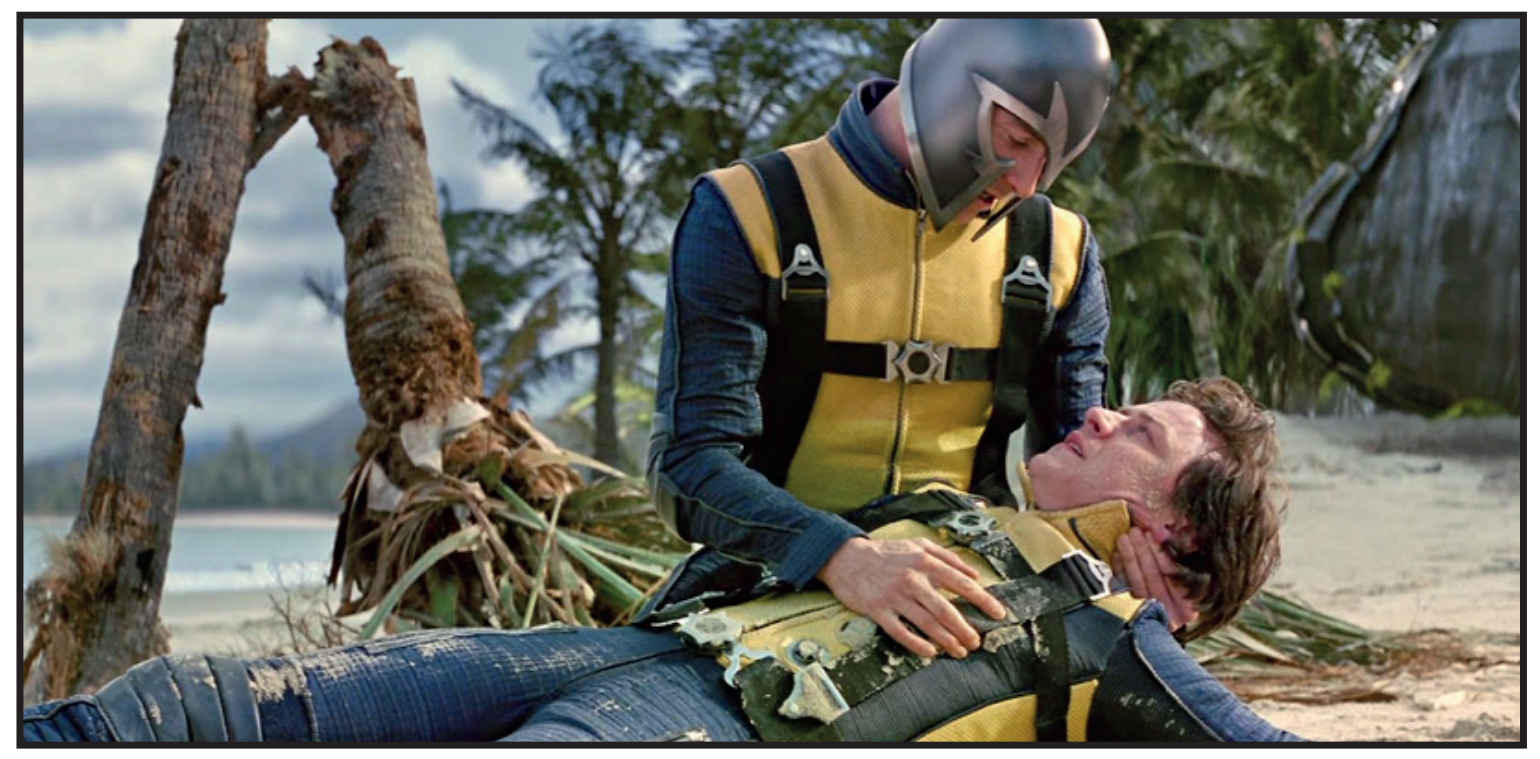

FIG. 14. X-Men: Primera Generación (X: First Class. Matthew Vaughn, 2011). 
planificación y el montaje, con una mirada privilegiada sobre el zeitgeist cultural de las últimas cuatro décadas. No hay más que comparar X-Men: Primera Generación (X: First Class. Matthew Vaughn, 2011) con una película diríase que similar por muchas razones, $X-M e n$ : Dias del futuro pasado (X-Men: Days of Future Past. Bryan Singer, 2014), y sin embargo mucho menos inspirada.

EM: Si hablamos de películas de superhéroes un tanto sui generis, incluso de esa mezcla enriquecedora de lo superheroico con otros géneros, también convendría hacerse eco de esas películas que, sin ser en absoluto de superhéroes, están llenas de imágenes que cualquier lector o lectora de superhéroes ha llegado a pensar: «¿Por qué no he visto yo esto todavía en ninguna película?»; que, a la vez, suponen quizás una permeabilidad fructífera del género en otros. El retrato como guardiana de los bosques de la protagonista de Maléfica (Maleficent. Robert Stromberg, 2014), así como su conversión en villana, tienen un carácter bastante épico y emancipador, al menos hasta que Disney hace de ella una madrastra / madre ejemplar que tutela domésticamente a la princesa Aurora. Otro tanto podría decirse de Elsa en Frozen: El reino del bielo (Frozen. Chris Buck y Jennifer Lee, 2013); abocada por el mundo a ser malvada, Elsa abraza su rol como tal en un momento de vindicación de sus superpoderes, el célebre y exultante momento musical Let It Go, capaz de poner a medio mundo a los pies de una villana e identificarse con ella, porque lo único que está haciendo en realidad es dar voz plena a su auténtica naturaleza interior, reprimida hasta entonces. Todo eso mientras Disney no la hace volver al redil, como acaba sucediendo. Por su parte, la relectura de los vampiros a cargo de la escritora Stephenie Meyer en la saga Crepúsculo tiene muchas tonalidades superheroicas, como ha constatado la ensayista y realizadora bosnia Lejla Panjeta, ${ }^{15}$ algo que subraya en este tipo de películas la puesta en escena: en la primera de ellas, Crepúsculo (Twilight. Catherine Hardwicke, 2008), los momentos en que Edward recupera la manzana que se le ha caído a Bella, frena con una sola mano un vehículo sin control, o se exhibe al sol y brilla casi como Superman; pero, sobre todo, destaquemos esa gran escena de batalla entre criaturas sobrenaturales en la última entrega, La saga Crepuisculo: Amanecer - Parte 2 (The Twilight Saga: Breaking Dawn - Part 2. Bill Condon, 2012), que es el sueño húmedo de cualquier seguidor de los X-Men; su amplitud de marco, su mirada es más salvaje y heroica que lo visto en cualquiera de las películas sobre los mutantes producidas por la Fox. Y el hecho de que se descubra que es tan solo una visión, tiene aún más mérito: se ha tentado a un público reacio a un tipo de imágenes violentas, propias de una epopeya, y luego se les ha devuelvo en apariencia intactos a su mundo. Hay ahí una vía de infiltración, de subversión. Y qué decir de la saga Resident Evil, sin argumentos casi a partir de cierto momento, libradas las imágenes a todo tipo de locuras de las que han sido cómplices la influencia de Matrix, la publicidad y los videojuegos, una permeabilidad absoluta de la imagen a toda influencia imaginable, que rompe con cualquier expectativa. Y, en medio de todo ello, la figura de Milla Jovovich como Alice Abernathy, que, a nivel si se quiere meramente icónico y de actitud, ha devenido «una heroína de acción con habilidades impresionantes», ${ }^{16}$ una superheroína ejemplar.

${ }_{15}$ Panjeta, L. «Monster as a Superhero: An Essay on Vampire Vogue in Contemporary Film Culture», en Studii Şi Cercet. IST. ART. Teatru, Muzică, Cinematografie, serie nouă, T. 5-6 (49-50), (2011-2012), pp. 11-20.

${ }_{16}$ Dendle, P. The Zombie Movie Encyclopedia, Volume 2: 2000-2010, Jefferson NC, McFarland, 2012, p. 167. 
DS: Visto así, podríamos atrevernos a decir que se trata de películas más experimentales de lo que podríamos encontrar en un ámbito que hasta ahora no habíamos abordado, el de la animación. En líneas generales, no he logrado percibir una línea revolucionaria en este ámbito, una mirada especial. Me parece relevante por ejemplo Megamind (íd. Tom McGrath, 2010), una producción de DreamWorks Animation complementaria en cierto modo de $E l$ Protegido, por cuanto en ella un villano pierde la ilusión de vivir una vez ha derrotado a su némesis superheroica; creo que es una película que trata sin cortapisas qué significa tener superpoderes, y la relación de ello con las nociones de Bien y Mal, con unos trazos entre lo estilizado y lo caricaturesco.

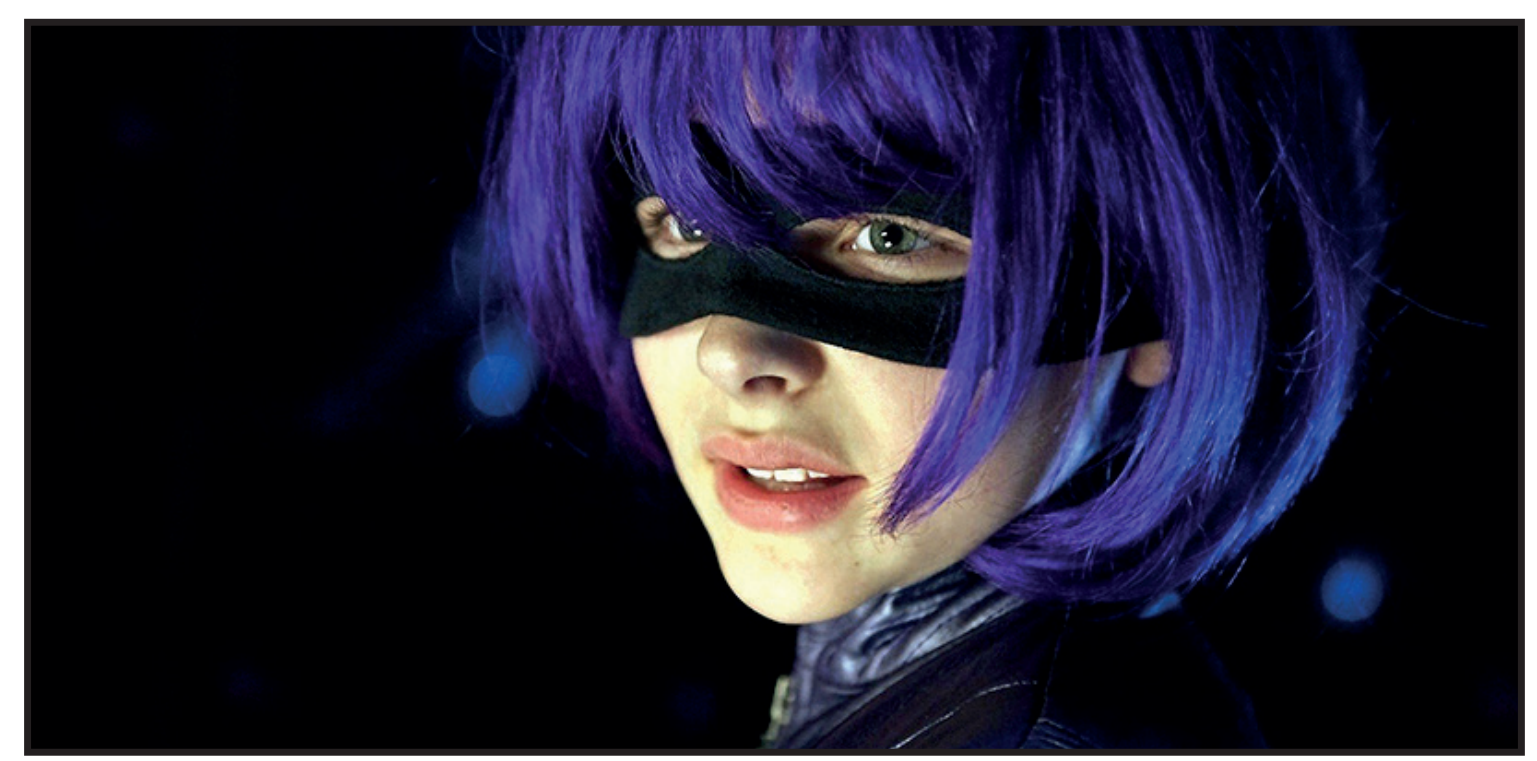

FIG. 15. Kick-Ass 2 - Con un par (Kick-Ass 2. Jeff Wadlow, 2013).

Más realista, hasta el punto de que en el momento de su estreno se lamentó que la coetánea Los cuatro fantásticos de Tim Story no fuera así de buena, era Los increíbles (The Incredibles. Brad Bird, 2004), muy bien realizada pero como podría estarlo una entrega inspirada de las sagas 007 o Mission: Impossible. Y Big Hero 6 (íd. Chris Williams \& Don Hall, 2014) se situaría quizás entre ambas: por un lado, es radiante a nivel visual en los momentos espectáculo, y, por otra, se vuelve terriblemente pragmática cuando toca dar la primacía al relato, lo dramático, las convenciones de siempre. Y luego están todas esas producciones corporativas de animación gestadas con frecuencia en Marvel o DC, pongamos por caso Planet Hulk (íd. Sam Liu, 2010) o All-Star Superman: Superman viaja al sol (Sam Liu, 2011), dirigidas a los fans acérrimos de los cómics, y en mi opinión muy poco trabajadas pese al predicamento que han llegado a tener algunos implicados frecuentes en ellas, como el director Sam Liu o el guionista Dwayne McDuffie. Para mí, no logran en casi ningún momento ser otra cosa que versiones sofisticadas de los dibujos animados de siempre sobre superhéroes que ha podido ver uno las mañanas de los sábados en la televisión, con gráficos y planificación muy esquemáticos. Tú me has reiterado que valen la pena en ocasiones por el rumbo dramático que toman a veces en ellas los personajes en relación a los cómics; pero, a nivel estrictamente plástico, me parecen mediocres. 
EM: Pero no menos mediocres que muchas producciones de la Marvel en imagen fotorrealista. Yo veo la serie Teenage Mutant Ninja Turtles (Ciro Neili, Joshua Sternin y J.R. Ventimilia para Nickelodeon,2012-), o lo que ha hecho un Bruce Timm - prolífico tanto en el ámbito del cómic como de la animación - en algunas de las producciones corporativas a que aludías, y las considero más creativas que lo ofrecido por Kevin Feige en Marvel. Hasta ahora solo hemos hablado tangencialmente de las películas Marvel, pero creo que ha llegado la hora de hacer un repaso a lo que han dado de sí en términos formales. Tanto da si, cuando, en años previos, sus superhéroes eran tratados por otros estudios; a partir de que Marvel adquiriese poder más o menos absoluto sobre sus personajes de cómic; o cuando fue absorbida por Disney en 2009, momento en que quizá se precipitó un universo cinemático Marvel en fases, como una línea de productos con una proyección utilitarista y un horizonte insaciable de potenciales beneficios. No es difícil percibir que, tras una Fase I en la que se requirieron nombres con cierto background y cualidades variadas - Jon Favreau, Kenneth Branagh, Joe Johnston-, capaces de dar a las imágenes una singularidad, un valor distintivo que te hacía saber de inmediato qué superhéroe en concreto estabas viendo y el tono de sus aventuras, una vez establecido el modelo Marvel se ha ido bajando el listón, y no ya en lo que se refiere a los directores sino en casi todos los aspectos técnicos, siempre dentro de un orden férreo de producción que es al fin y al cabo lo más creativo de sus películas.

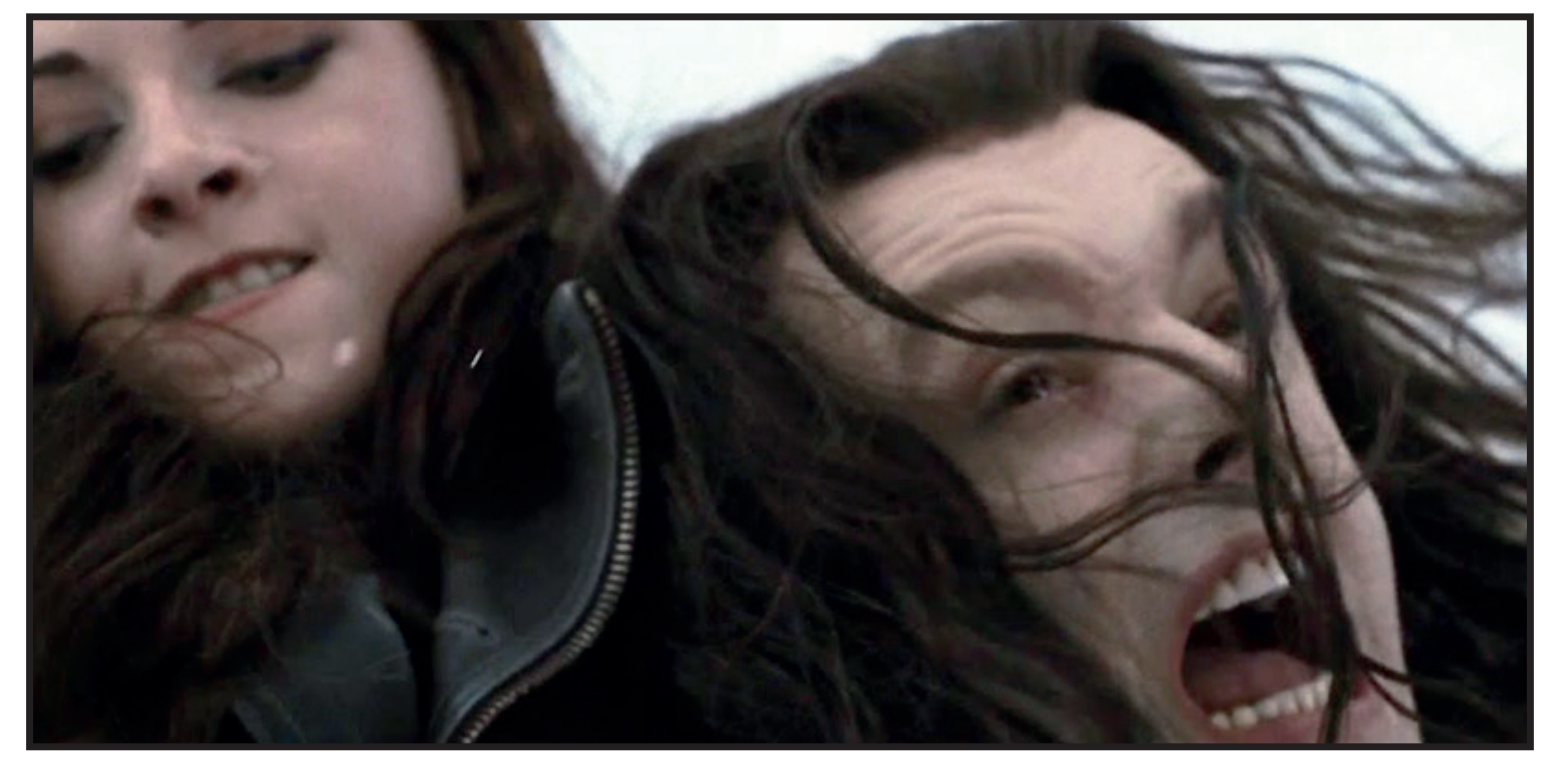

FIG. 16. La saga Crepuisculo: Amanecer, Parte 2 (Twilight Saga: Breaking Dawn, Part 2. Bill Condon, 2012).

En ellas nunca chirría nada, pero dentro de una homogeneidad creciente, un mismo rango de la imagen. Y, como les funciona, esto acabará desembocando en un estilo de producción similar a la saga Bond, en el que la creatividad no es que sobre, es que puede llegar a ser un problema; no olvidemos al respecto las deserciones en unos u otros momentos por las consabidas «diferencias creativas» de Jon Favreau, Edgar Wright... Por ello, que Disney continúe recurriendo a nombres con algún peso específico — pienso en Shane Black o James 
Gunn, crucemos los dedos en cuanto a Doctor Extraño- es por aquello de que los márgenes alimenten el centro, lo legitimen y adornen anímicamente, por así decirlo; aunque, en el fondo, más allá de rasgos de carácter superficiales que se distingan allí y allá, nada va a ser sustancialmente distinto. Saben además que es efectivo de cara a la crítica, porque - por razones de mixtificación varias - la aparición de nombres como Kenneth Branagh o James Gunn hace que se desaten automatismos analíticos, y se señale respectivamente un espíritu shakesperiano o gamberro que, en la práctica, no se ve por ninguna parte o que, en comparación con películas realmente inspiradas de los mismos directores, son apenas sombras del pasado, parodias. Sucede así que un repaso por la imagen Marvel hasta la fecha permite salvar el tono pulp y neoclasicista de Capitán América: El primer vengador, la innegable eficacia de los hermanos Joe y Anthony Russo en las siguientes dos entregas del Capitán América, la brillantez de que hablabas a propósito de Iron Man, y, quizás, los primeros minutos de Vengadores: Era de Ultrón; en los que, a base de imágenes en formato panorámico que conjugaban las estrategias del videojuego inmersivo y las splash pages de una historieta, su director parecía estar pidiendo disculpas por Los Vengadores (The Avengers. Joss Whedon, 2012), película que respiraba televisión por los cuatro costados en lo que se refiere a la imagen. Por lo demás, títulos como Ant-Man (íd. Peyton Reed, 2015), Guardianes de la Galaxia, o Thor y su secuela, evidencian una domesticidad absoluta de las imágenes en términos figurados y literales, que resulta todavía más hiriente si se tiene en cuenta que los universos de lo microscópico y lo macroscópico, la space opera, o Asgard y demás escenarios habituales del Dios del Trueno, tenían el potencial, y así lo han demostrado una y otra vez en las viñetas, de dar alas al sentido de la maravilla, del terror, de la belleza, que sí podía percibirse por otra parte en una película también de gran estudio como Hellboy 2. El ejército dorado (Hellboy II: The Golden Army. Guillermo del Toro, 2009) gracias a la mirada de quien la firmaba.

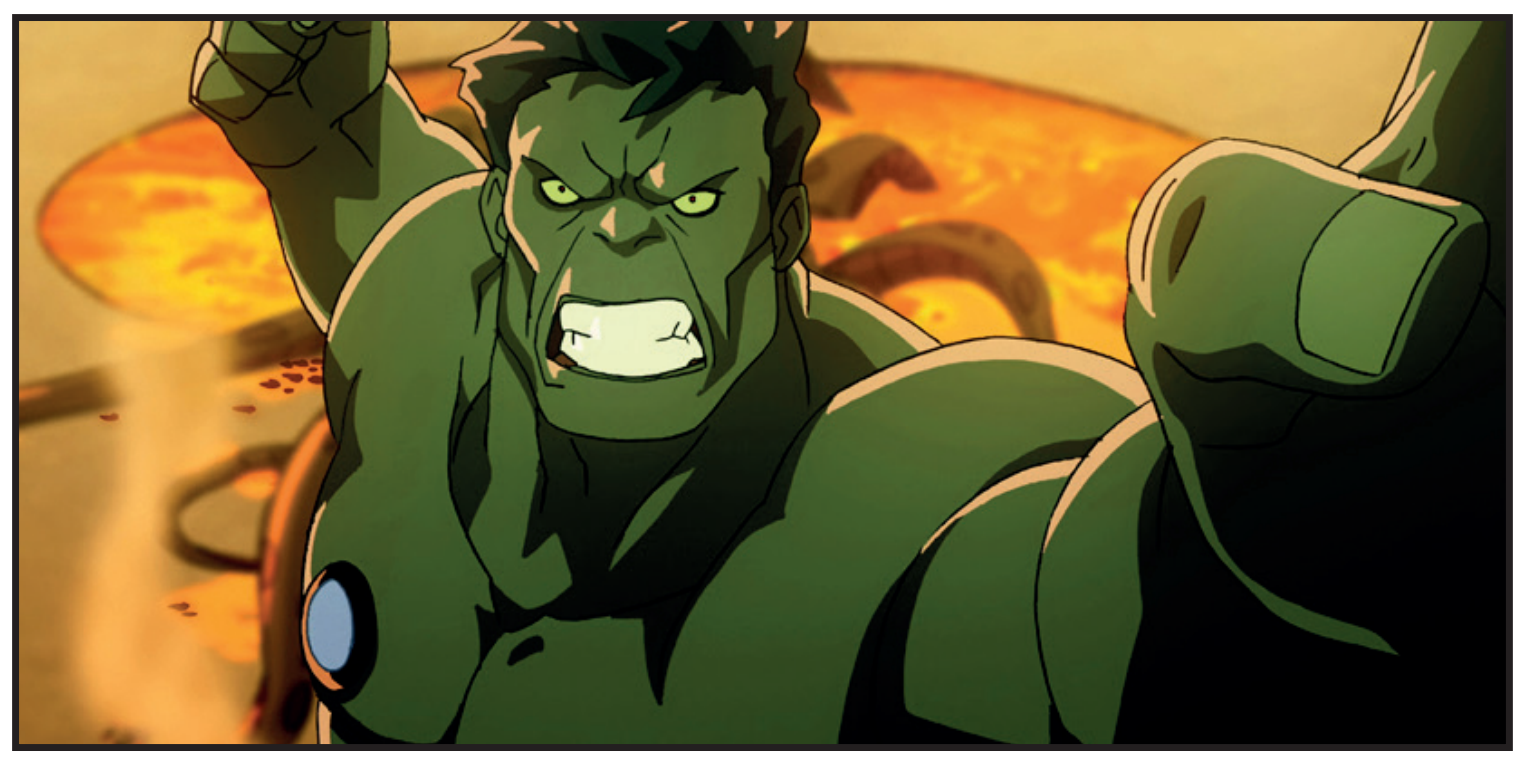

FIG. 17. Planet Hulk (íd. Sam Liu, 2010).

DS: Curiosamente, varios problemas que planteas revalidan un nombre aparecido en varios momentos de nuestra charla, y que, en mi opinión, representa el único grado de autoría 
recurrente que ha podido percibirse hasta el momento en este boom contemporáneo de los superhéroes, quitando las aportaciones puntuales de Tim Burton, M. Night Shyamalan, Sam Raimi, Christopher Nolan o Matthew Vaughn, o el caso Bryan Singer, que, como hemos comentado, no termina de cuajar.

Me refiero a Zack Snyder, quien, desde luego, tiene un perfil mucho menos intelectual que Shyamalan o Nolan — de hecho, se le tilda a menudo de garrulo, lo que yo reivindico por cierto como una cualidad-, y al que esta distinción de la que hablo como autor podría ser justo aplicársela en buena medida al peso, ya que, entre unas cosas y otras, de las siete películas que ha realizado hasta la fecha, cuatro están ligadas de manera directa y con tics muy reconocibles al campo de los superhéroes y asimilados, aunque hayan sido acogidas por crítica y aficionados con enorme división de opiniones: 300, Watchmen, El hombre de acero y Batman v Superman: El amanecer de la justicia. Snyder es, en mi opinión, un director de tremendas facultades para la creación de una iconicidad espectáculo, para la transmutación del kitsch pop en imagen sublime. ${ }^{17}$ Ahora bien, su fuerte son la asimilación y regurgitación primarias y sincréticas - en nombre, por cierto, de un discurso empoderador muy agresivo, que nos habla de nuestra propia indolencia para escapar a la prisión de un universo sociocultural estragado por el uso y el abuso-, lo que choca de frente con la sumisión a marcas concretas muy establecidas en el imaginario popular con unos u otros signos. Por eso su culmen es Sucker Punch (íd. Zack Snyder, 2011), abstracción absoluta de propia cosecha a partir de toda una vida absorbiendo audiovisual media —cine, música, televisión, cómics, videojuegos, publicidad...-, mientras que, con los Watchmen de Alan Moore y Dave Gibbons, o el Superman de la DC, se siente en buena medida atado de pies y manos, y sus ficciones lo transmiten: su fidelidad mal entendida al Watchmen impreso hacen su versión indigerible, cuando debería haber releído una obra maestra de lo cerebral desde lo visceral; mientras que el personaje encarnado por Henry Cavill en sus dos películas sobre Superman es un peligroso idiota moral. ${ }^{18}$ Quiero ser optimista y pensar que, si Snyder logra escapar con vida de la encerrona en que él mismo se ha metido con Warner / DC, puede volver a darnos alegrías. Y, en cualquier caso, me parece que no es poca cosa que, hasta en películas tan desastrosas para mí como Batman $v$ Superman: El amanecer de la justicia, siempre haya momentos que vulneran esa asepsia cuqui, esa pulcritud emasculada del muñeco a salvo en su blíster inmaculado, que creo, ambos coincidimos, está haciendo bastante daño a las posibilidades de la imagen superheroica, tanto en pantalla como en viñetas: esas referencias jesucrísticas y nietzscheanas, ese Superman / Clark Kent que se cuela en la bañera de Lois Lane con modos algo prepotentes - en el cine de Snyder hay sexo, y hay una voluntad de poder asociada al sexo-, esa aparición de una Wonder Woman en clave muy similar a los espartanos de 300 - sus mujeres siempre han sido combativas y han estado a la par con sus hombres-, esa colisión de los imaginarios pop tan opuestos que representan Superman y Batman...

\footnotetext{
${ }^{17}$ SAlgado, D. «El hombre sin miedo: Zack Snyder», en Miradas de Cine (22/ de marzo de 2009). Disponible online en http://archivo.miradasdecine.es/actualidad/2009/03/zack-snyder.html

18 Salgado, D. «Idiota moral: El hombre de acero», en Miradas de Cine (27 de junio de 2013). Disponible online en http://archivo.miradasdecine.es/criticas/2013/06/el-hombre-de-acero.html
} 


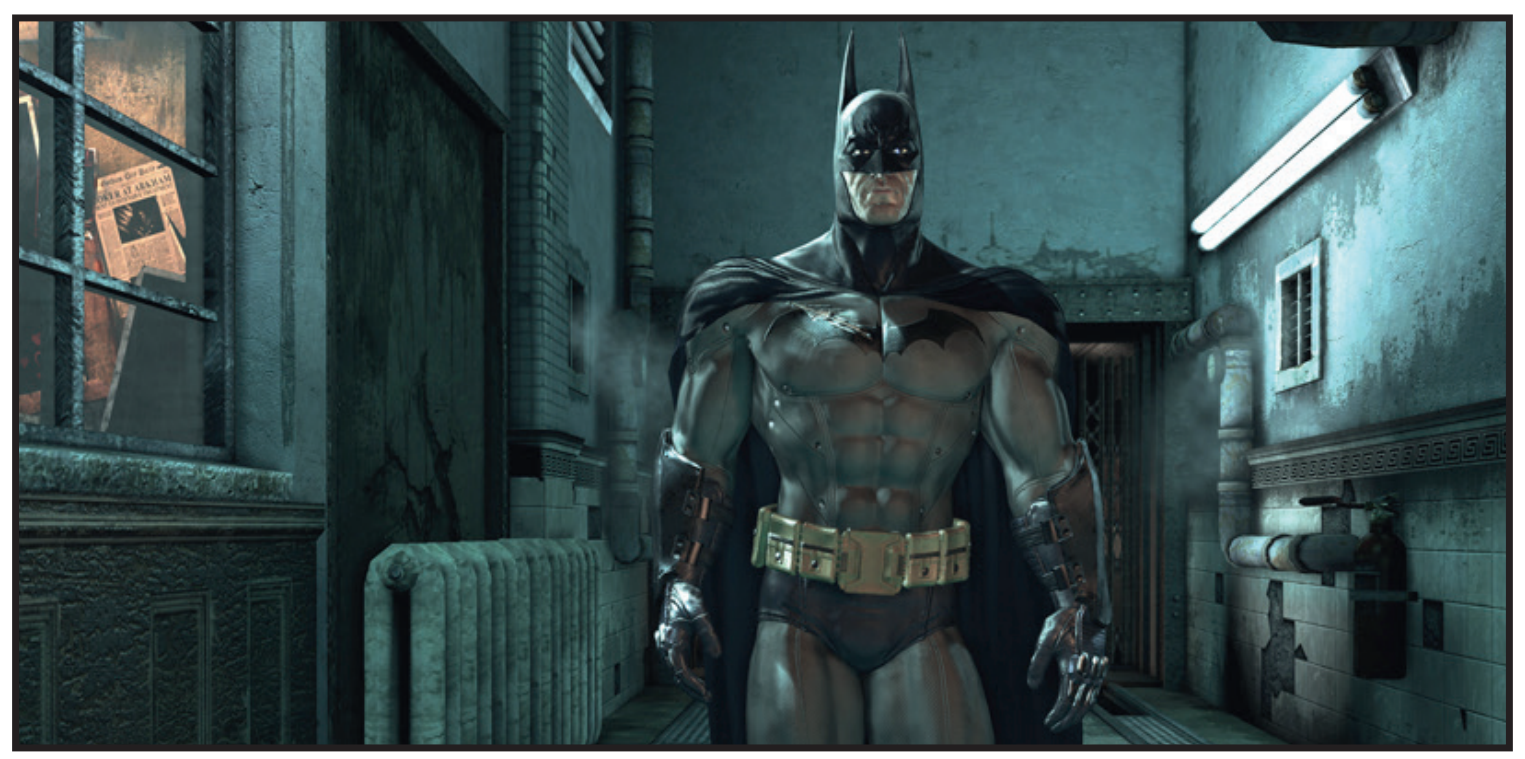

FIG. 18. Batman: Arkham Asylum (Rocksteady

Studios para Eidos / WB, 2009).

EM: La jaula de oro en la que se ha encerrado Snyder dice mucho del ritmo y el rumbo todopoderoso de producción que, de forma más o menos accidentada, Marvel y Warner / DC han impuesto a las películas y series de superhéroes, y lo que ello implica en términos de creatividad. Que ahora mismo, mayo de 2016, sepamos qué vamos a ver y en qué fecha exacta de 2019 o 2020, es un indicativo de la falta de atrevimientos significativos esperables, más allá de una perfección creciente en los efectos visuales que, por ahora, redunda solo en una mayor convicción de lo fotorrealista pero poco en su cuestionamiento, en que nos interroguemos sobre la condición misma de la imagen en movimiento y sus convenciones representativas cuando es penetrada por la especulación o el puro fantástico. Habrá que estar muy atentos a esas películas que, como hemos hablado, incluso en el seno mismo de la industria se convierten por sorpresa en platillos volantes; o a esas otras adscritas más o menos al imaginario indie que puedan surgir, como hasta hoy Super, Special (Hal Haberman \& Jeremy Passmore, 2006) o Defendor (Peter Stebbings, 2009). O, también, dado que el fenómeno del superhéroe se ha globalizado, a películas de otras nacionalidades que, por hibridación, puedan violentar los consensos del género en torno a qué puede aceptar o no el gran público en pantalla. En lo mainstream, veo ahora mismo posibilidad de riesgo solo si las películas empiezan a pinchar en taquilla y, como hemos comentado tú y yo a veces, empiezan a relajarse los estándares de producción, a darse luz verde a los experimentos a la desesperada y a las mezclas improbables. Y, por otra parte, tampoco es descartable que la influencia creciente de los videojuegos en el panorama del entretenimiento - por ejemplo, la sinergia entre la narrativa de Paul Dini y los gráficos de Rocksteady hacían de Batman: Arkham Asylum (2009) toda una experiencia-, a lo que hay que sumar un posible boom de los cascos de realidad virtual, fuerce cambios en los planteamientos formales del audiovisual superheroico. Lo único cierto hoy por hoy es que no hay nadie parecido a Alan Moore, Osamu Tezuka, Neal Adams o Frank Miller filmando películas, ni un estudio dispuesto a apostar por un equivalente cinematográfico de cualquiera de ellos, ni una filosofía de ex- 


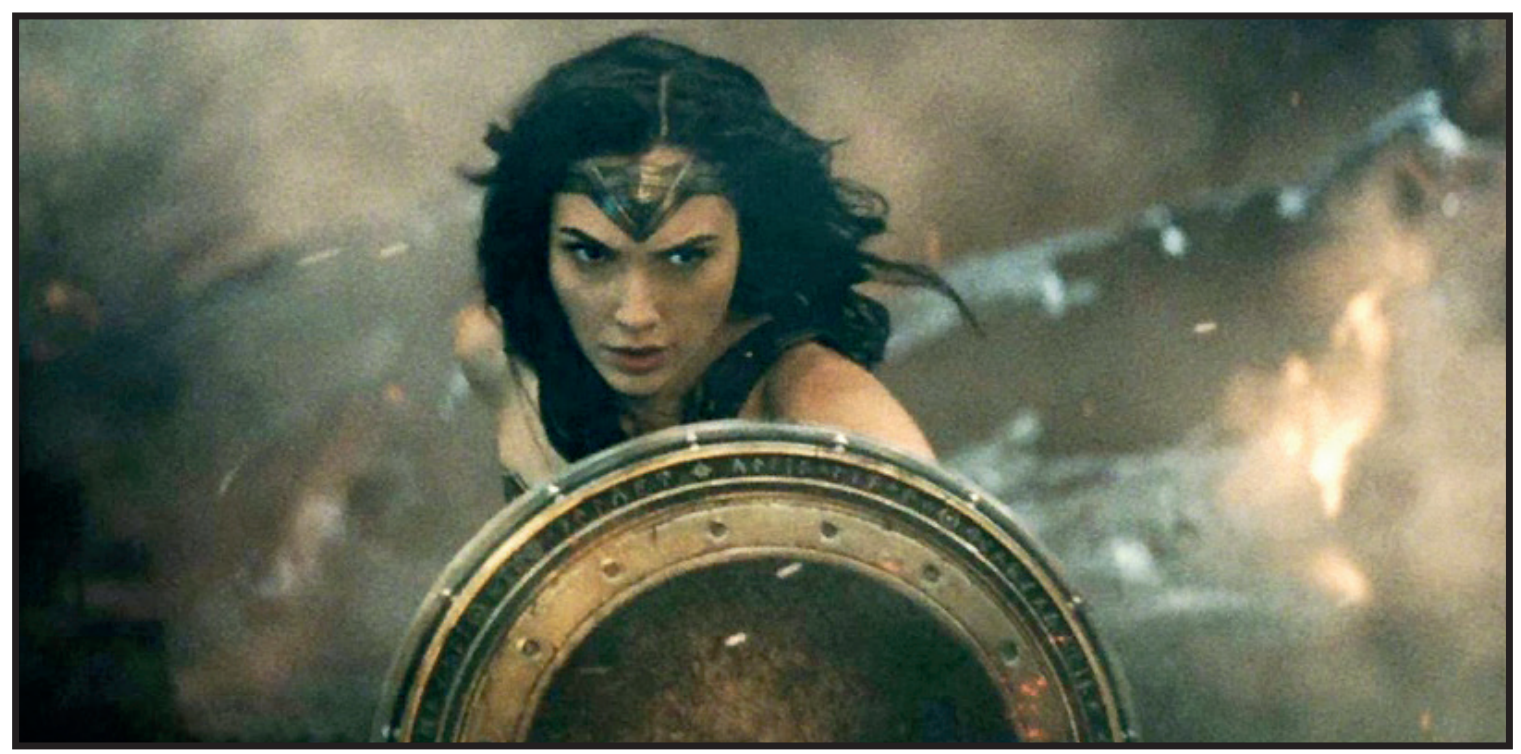

FIG. 19. Presentación en Batman v Superman: El amanecer de la justicia (Batman v Superman: Dawn of Justice. Zack Snyder, 2016) de Wonder Woman, protagonista en solitario de la película dirigida por Patty Jenkins que se estrenará en 2017.

plotar siquiera en nombre del espectáculo los efectos visuales, más allá de lo enunciativo en cuanto a superpoderes y destrucción.

Las películas de superhéroes se han convertido en la manifestación contemporánea por antonomasia de los grandes espectáculos de Hollywood y, de forma inversa, «para el éxito de las adaptaciones al cine de los comic books de superhéroes, ha sido clave la asimilación de las fórmulas de los blockbusters». ${ }^{19}$ Así, han triunfado por completo en lo que se refiere a popularidad y continuidad en la esfera pública. Pero continuidad no es lo mismo que evolución: no estamos lejos del panorama que definieron en 2008 Iron Man y El caballero oscuro. Puede incluso que haya habido una regresión. Es hora de exigirle, de que el género se exija a sí mismo, más.

${ }_{19}$ Foster, C. «Marvel vs. DC Mergers, Acquisitions and Corporate Rebranding in the New Millennium», en Cinephile, vol. 9, n. 2: The Superhero Film, (otoño, 2013). 